\title{
Variability in climate and productivity during the Paleocene-Eocene Thermal Maximum in the western Tethys (Forada section)
}

\author{
L. Giusberti ${ }^{1}$, F. Boscolo Galazzo ${ }^{1}$, and E. Thomas ${ }^{2,3}$ \\ ${ }^{1}$ Department of Geosciences, University of Padova, Via Gradenigo 6, 35131 Padua, Italy \\ ${ }^{2}$ Department of Geology and Geophysics, Yale University, 210 Whitney Avenue, New Haven, CT 06511, USA \\ ${ }^{3}$ Department of Earth and Environmental Sciences, Wesleyan University, 265 Church Street, Middletown, CT 06459, USA
}

Correspondence to: L. Giusberti (luca.giusberti@unipd.it)

Received: 14 July 2015 - Published in Clim. Past Discuss.: 4 September 2015

Revised: 31 December 2015 - Accepted: 16 January 2016 - Published: 9 February 2016

\begin{abstract}
The Forada section (northeastern Italy) provides a continuous, expanded deep-sea record of the PaleoceneEocene Thermal Maximum (PETM) in the central-western Tethys. We combine a new, high-resolution, benthic foraminiferal assemblage record with published calcareous plankton, mineralogical and biomarker data to document climatic and environmental changes across the PETM, highlighting the benthic foraminiferal extinction event (BEE). The onset of the PETM, occurring $\sim 30 \mathrm{kyr}$ after a precursor event, is marked by a thin, black, barren clay layer, possibly representing a brief pulse of anoxia and carbonate dissolution. The BEE occurred within the $10 \mathrm{~cm}$ interval including this layer. During the first $3.5 \mathrm{kyr}$ of the PETM, several agglutinated recolonizing taxa show rapid species turnover, indicating a highly unstable, $\mathrm{CaCO}_{3}$-corrosive environment. Calcareous taxa reappeared after this interval, and the next $\sim 9 \mathrm{kyr}$ were characterized by rapid alternation of peaks in abundance of various calcareous and agglutinated recolonizers. These observations suggest that synergistic stressors, including deepwater $\mathrm{CaCO}_{3}$ corrosiveness, low oxygenation, and high environmental instability caused the extinction. Combined faunal and biomarker data (BIT index, higher plant $n$-alkane average chain length) and the high abundance of the mineral chlorite suggest that erosion and weathering increased strongly at the onset of the PETM, due to an overall wet climate with invigorated hydrological cycle, which led to storm flood events carrying massive sediment discharge into the Belluno Basin. This interval was followed by the core of the PETM, characterized by four preces-
\end{abstract}

sionally paced cycles in $\mathrm{CaCO}_{3} \%$, hematite $\%, \delta^{13} \mathrm{C}$, abundant occurrence of opportunistic benthic foraminiferal taxa, and calcareous nannofossil and planktonic foraminiferal taxa typical of high-productivity environments, radiolarians, and

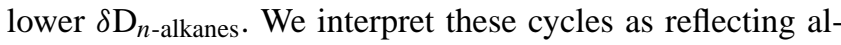
ternation between an overall arid climate, characterized by strong winds and intense upwelling, and an overall humid climate, with abundant rains and high sediment delivery (including refractory organic carbon) from land. Precessionally paced marl-limestone couplets occur throughout the recovery interval of the carbon isotope excursion (CIE) and up to $10 \mathrm{~m}$ above it, suggesting that these wet-dry cycles persisted, though at declining intensity, after the peak PETM. Enhanced climate extremes at mid-latitudes might have been a direct response to the massive $\mathrm{CO}_{2}$ input in the ocean atmosphere system at the Paleocene-Eocene transition, and may have had a primary role in restoring the Earth system to steady state.

\section{Introduction}

The Paleocene-Eocene Thermal Maximum (PETM) has over the last 24 years attracted intensive study by the scientific community as one of the most dramatic and rapid climatic disruptions of the Cenozoic (e.g., Kennett and Stott, 1991; Zachos et al., 2001; Sluijs et al., 2007a; McInerney and Wing, 2011; Littler et al., 2014). During the PETM ( $\sim 55.6 \mathrm{Ma})$, the Earth's surface temperature increased by $\sim 5^{\circ} \mathrm{C}$ in a few thousand years (McInerney and Wing, 2011; 
Dunkley-Jones et al., 2013; Zeebe et al., 2014; Bowen et al., 2015), and remained high for 100 to 170-200 kyr (e.g., Röhl et al., 2007; Giusberti et al., 2007; Murphy et al., 2010). The PETM is recognized in terrestrial and marine settings by a negative carbon isotope excursion (CIE; e.g., Kennett and Stott, 1991; Bowen et al., 2004), with variable magnitude ranging from $\sim 2-4.5 \%$ in marine carbonates (e.g., Thomas and Shackleton, 1996; Bains et al., 1999; Thomas et al., 2002; Zachos et al., 2006; Handley et al., 2008; McCarren et al., 2008) to 4-7\%o in marine and terrestrial organic carbon and leaf waxes (e.g., Kaiho et al., 1996; Bowen et al., 2004, 2015; Pagani et al., 2006a; Smith et al., 2007; Handley et al., 2008; McCarren et al., 2008). This CIE is attributed to a massive, rapid input of isotopically light carbon into the ocean-atmosphere system which destabilized the global carbon cycle and led to rapid and extreme global warming (e.g., Dickens et al., 1997; Thomas and Shackleton, 1996; Pagani et al., 2006b; Panchuk et al., 2008; Dickens, 2011; DeConto et al., 2012). Both the source(s) of the carbon and the triggering mechanism(s) of the emissions are still strongly debated (e.g., Meissner et al., 2014), in part because the pattern and size of the CIE does not necessarily simply reflect the size and isotopic signature of the carbon input, but is affected by biotic and sedimentary processes (e.g., Kirtland Turner and Ridgwell, 2013). Despite these debates, the onset of the CIE is an outstanding global correlation tool (McInerney and Wing, 2011; Stassen et al., 2012b), formally used to define the base of the Eocene (Aubry et al., 2007).

The carbon cycle perturbation of the PETM led to acidification of surface ocean waters (Penman et al., 2014) and severe shallowing of the calcite compensation depth (CCD; Zachos et al., 2005; Kelly et al., 2010; Hönisch et al., 2012). Widespread carbonate dissolution coincided with the base of the CIE (e.g., Thomas and Shackleton, 1996; Thomas, 1998; Hancock and Dickens, 2005; McCarren et al., 2008). The paleoceanographic changes affected primary and export productivity (e.g., Thomas, 2007; Winguth et al., 2012; Ma et al., 2014), which in general increased in marginal basins and along continental margins but decreased in open oceans (e.g., Gibbs et al., 2006; Stoll et al., 2007; Speijer et al., 2012). The higher ocean temperatures may have led to increased remineralization of organic matter in the oceans due to increased metabolic rates (John et al., 2013, 2014; Boscolo Galazzo et al., 2014; Ma et al., 2014). The combination of increased remineralization, higher temperatures and increased ocean stratification led to a decrease in oxygen levels in bottom waters regionally, especially along continental margins (including the Arctic Ocean) and in the Atlantic Ocean (e.g., Benjamini, 1992; Speijer et al., 1997, 2012; Gavrilov et al., 1997; Thomas, 2007; Chun et al., 2010; Winguth et al., 2012; Nagy et al., 2013; Wieczorek et al., 2013; Dickson et al., 2014; Pälike et al., 2014; Post et al., 2016), while oxygen minimum zones in open oceans expanded globally (Zhou et al., 2014), including at Forada (Luciani et al., 2007).
The increased primary productivity in marginal basins has been linked to increased influx of nutrients from the continents, caused by increased erosion and weathering due to intensification of the hydrological cycle, because precipitation is correlated to globally averaged surface temperatures (e.g., Pierrehumbert, 2002). A widespread increase in kaolinite in PETM sediments has been related to the global increase in precipitation and intensity of chemical weathering (e.g., Robert and Chamley, 1991; Robert and Kennett, 1994; Kaiho et al., 1996; Gibson et al., 2000), as also suggested by Os-isotope evidence (Ravizza et al., 2001; Wieczorek et al., 2013). However, reconstruction of hydrological changes from clay mineral assemblages is complex, and additional evidence is needed (Thiry, 2000; Schmitz and Pujalte 2003, 2007; Egger et al., 2003, 2005; Handley et al., 2012).

The severe climatic perturbations of the PETM profoundly affected terrestrial and marine ecosystems, triggering faunal and floral radiations and migrations (e.g., Kelly et al., 1996; Bralower, 2002; Gingerich, 2003; Wing et al., 2005; Sluijs et al., 2007a; Jaramillo et al., 2010; McInerney and Wing, 2011). Deep-sea benthic foraminifera experienced the most severe extinction of the Cenozoic, the benthic foraminiferal extinction event (BEE) (Thomas, 1989, 1990, 1998; Kennett and Stott, 1991; Thomas and Shackleton, 1996; Alegret et al., 2009a, b; 2010). The BEE was rapid (<10 kyr; Thomas, $1989,2003,2007)$ and wiped out the Cretaceous bathyal and abyssal "Velasco-type fauna" (Berggren and Aubert, 1975; Tjalsma and Lohmann, 1983; Thomas, 1998, 2007), marking a significant step towards the establishment of modern benthic foraminiferal fauna (Thomas, 2007). The extinction was far less severe in shelf environments (Gibson et al., 1993; Speijer et al., 2012; Stassen et al., 2015).

The cause of this global extinction remains under debate, because neither anoxia nor higher or lower productivity nor carbonate dissolution occurred globally at bathyal to abyssal depths in the deep sea, the largest habitat on Earth (e.g., Thomas, 2003, 2007; Alegret et al., 2010), and benthic foraminifera are highly efficient dispersers (Alve and Goldstein, 2003). The link between the environmental changes during the PETM and the benthic foraminiferal extinction event thus remains poorly understood. A common obstacle to perform detailed high-resolution studies of the PETM in deep-sea sediments is the fact that many records are condensed or discontinuous, especially across the few thousand years (Zeebe et al., 2014) of the onset of the carbon isotope excursion. The Forada section (northeastern Italy) represents an outstanding exception in that it contains an expanded deep-sea record of the PETM, which has been extensively studied because of its continuity and cyclostratigraphy (Agnini et al., 2007; Giusberti et al., 2007; Luciani et al., 2007; Tipple et al., 2011; Dallanave et al., 2012). Carbonate dissolution is less severe at Forada than in many other sections, with calcareous benthic foraminifera present for most of the interval characterized by the CIE ( $>4 \mathrm{~m}$; Giusberti et al., 2007). Given the limited number globally of complete 
and expanded deep-sea PETM sections, the Forada section represents an invaluable opportunity to investigate the environmental impacts of the PETM and repercussions on deepsea fauna.

We provide a high-resolution benthic foraminiferal record for the Forada section in order to reconstruct the progression (tempo and mode) of environmental and biotic changes during the PETM. These data allow us to reconstruct the environmental disruption and the benthic foraminiferal response to PETM warming in detail and document the community recovery. Benthic foraminiferal data are integrated with sedimentological and geochemical data (Giusberti et al., 2007; Tipple et al., 2011), and data on calcareous plankton communities (Agnini et al., 2007; Luciani et al., 2007), providing perhaps the most complete reconstruction across the PETM in Europe to date.

We pay homage to research by the Italian researchers (Di Napoli Alliata et al., 1970; Braga et al., 1975) who first described the benthic foraminiferal turnover across the Paleocene-Eocene transition in Italy.

\section{Materials and methods}

\subsection{The Forada section}

The Forada section $\left(46.036083^{\circ} \mathrm{N}, 12.063975^{\circ} \mathrm{E}\right)$ is exposed along the Forada creek, $\sim 2 \mathrm{~km}$ east of the village of Lentiai (Fig. 1) in the Venetian Prealps (NE Italy). It consists of ca. $62 \mathrm{~m}$ of Scaglia Rossa, pink-reddish limestones and marly limestones, locally rhythmically bedded, and encompassing the Upper Cretaceous through the lower Eocene (Fornaciari et al., 2007; Giusberti et al., 2007). The upper Paleocenelower Eocene succession is interrupted by the clay marl unit (CMU; Giusberti et al., 2007), which marks the PETM and correlates with clay-rich units on other continental margins (e.g., Schmitz et al., 2001; Crouch et al., 2003; John et al., 2008; Nicolo et al., 2010). The investigated interval has been subdivided into four sub-intervals based on the $\delta^{13} \mathrm{C}$ record in bulk rock (Giusberti et al., 2007). From bottom to top, these are the pre-CIE, the main CIE, the CIE recovery and the post-CIE (Fig. 2). The main CIE (Giusberti et al., 2007; Figs. 2,3) occurs in the $>3 \mathrm{~m}$ thick CMU, within which are recorded the short-lived occurrences of the calcareous plankton "excursion taxa" (Kelly et al., 1996, 1998) and the BEE (Agnini et al., 2007; Giusberti et al., 2007; Luciani et al., 2007). Sedimentation rates in the CMU were 5 times higher than in the upper Paleocene, indicating increased continental weathering and runoff, which led to increased sediment influx in the Belluno Basin (Giusberti et al., 2007).

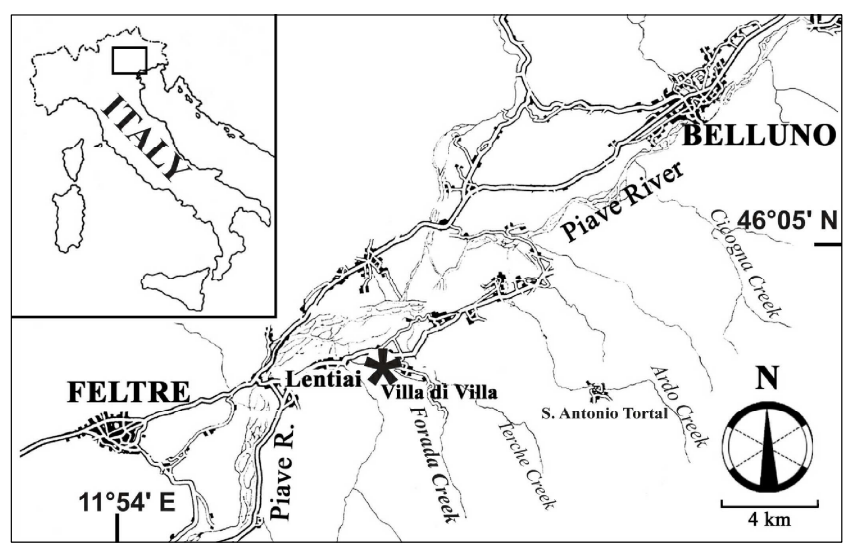

Figure 1. Location of the Forada section in the context of the Piave River valley in the province of Belluno (the "Valbelluna"), northeastern Italy.

\subsection{Benthic foraminifera}

Benthic foraminiferal assemblages were studied in 54 samples from the same set studied by Luciani et al. (2007) across an $\sim 11 \mathrm{~m}$ thick interval straddling the PETM $(-467$ to $+591.5 \mathrm{~cm}$; Fig. 2 ), which reflects $\sim 800 \mathrm{kyr}$ (Giusberti et al., 2007). In this study the planktic foraminifera fragmentation index ( $F$ index) of Luciani et al. (2007) is used as a proxy for dissolution (Figs. 2, 3) (Hancock and Dickens, 2005). The sample spacing for benthic foraminiferal assemblage analysis was determined based on biostratigraphic and cyclostratigraphic data (Agnini et al., 2007; Giusberti et al., 2007; Luciani et al., 2007). A sampling interval of $3-5 \mathrm{~cm}$ was used across the onset of the CIE $(-42.5$ to $+50 \mathrm{~cm}$ interval), a $25 \mathrm{~cm}$ sample interval over the main CIE (from +75 to $335 \mathrm{~cm}$ ). Below $-42.5 \mathrm{~cm}$ and above $335 \mathrm{~cm}$ we adopted a spacing between 20 and $50 \mathrm{~cm}$. Samples were collected excluding, to the extent possible, bioturbated material. Further selection and removal of bioturbated material was carried out in the laboratory before sample processing. Data previously collected from the Forada section indicate that significant bioturbation effects are not present (e.g., Agnini et al., 2007; Giusberti et al., 2007; Luciani et al., 2007).

Foraminifera were extracted from the indurated marls and limestones using the "cold acetolysis" technique of Lirer (2000), following Luciani et al. (2007). Soft marly and clayey samples (mostly from the CMU interval) were disaggregated using a $10-30 \%$ solution of hydrogen peroxide. The samples with the lowest content of $\mathrm{CaCO}_{3}$ (e.g., clays of basal $\mathrm{CMU}$ ) were treated with diluted hydrogen peroxide $(10 \%)$ in order to prevent possible additional breakage of tests (especially of planktic foraminifera). For more details on the comparison between the two methods of preparation (cold acetolysis versus hydrogen peroxide), we refer the reader to Luciani et al. (2007). 


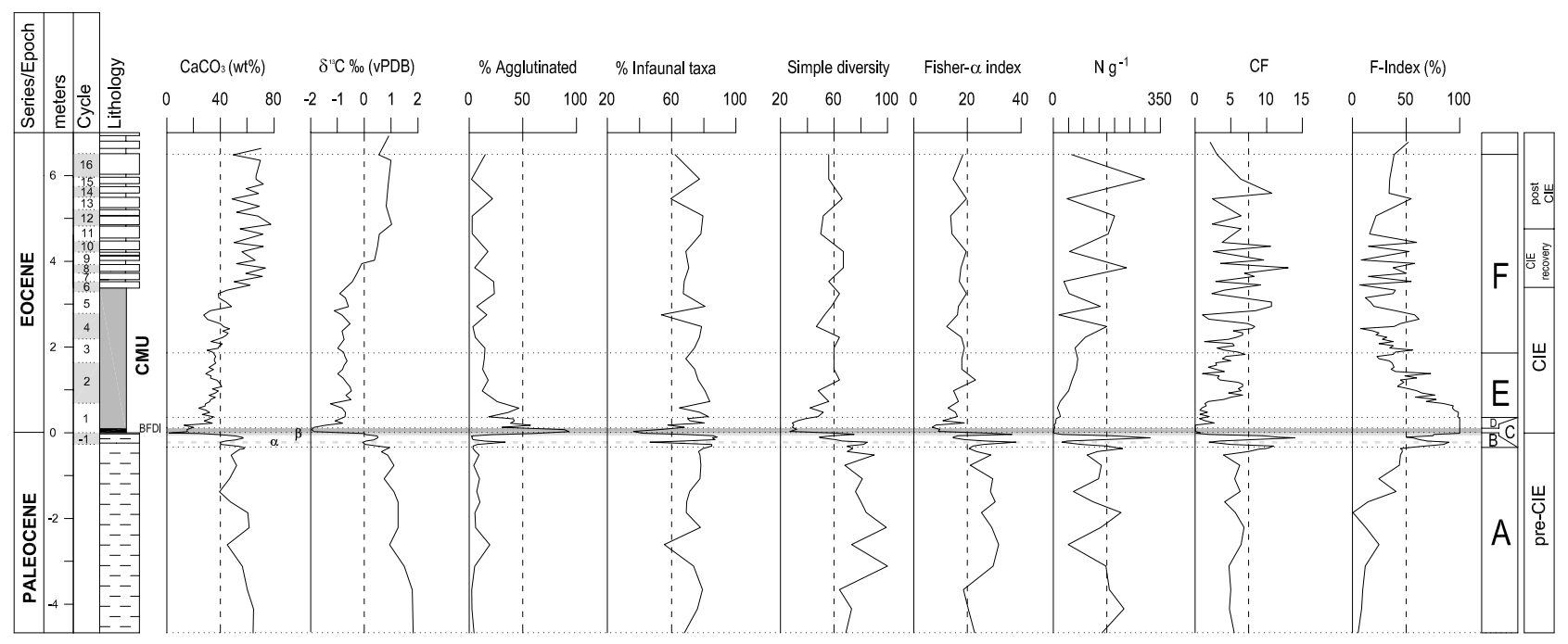

Figure 2. Faunal and geochemical variations across the PETM at the Forada section plotted against chronostratigraphy, precessional cycles, lithology, recognized benthic foraminiferal assemblages (A to F) and isotopic intervals. \% agglutinated: agglutinated to agglutinated and calcareous hyaline ratio; \% infaunal taxa: infaunal to infaunal and epifaunal ratio; simple diversity and Fisher- $\alpha$ diversity index; $\mathrm{Ng}^{-1}=$ number of benthic foraminifera per gram (faunal density) in the $>63 \mathrm{~mm}$ size fraction; coarse fraction (CF) calculated according to Hancock and Dickens (2005) as the weight percent of the $>63 \mu \mathrm{m}$ size fraction relative to the weight of the bulk sample; fragmentation index $(F$ index) is from Luciani et al. (2007). The gray bands indicate intervals of carbonate dissolution. $\alpha$ : pre-CIE dissolution, $\beta$ : burndown layer; BFDI: benthic foraminiferal dissolution interval.

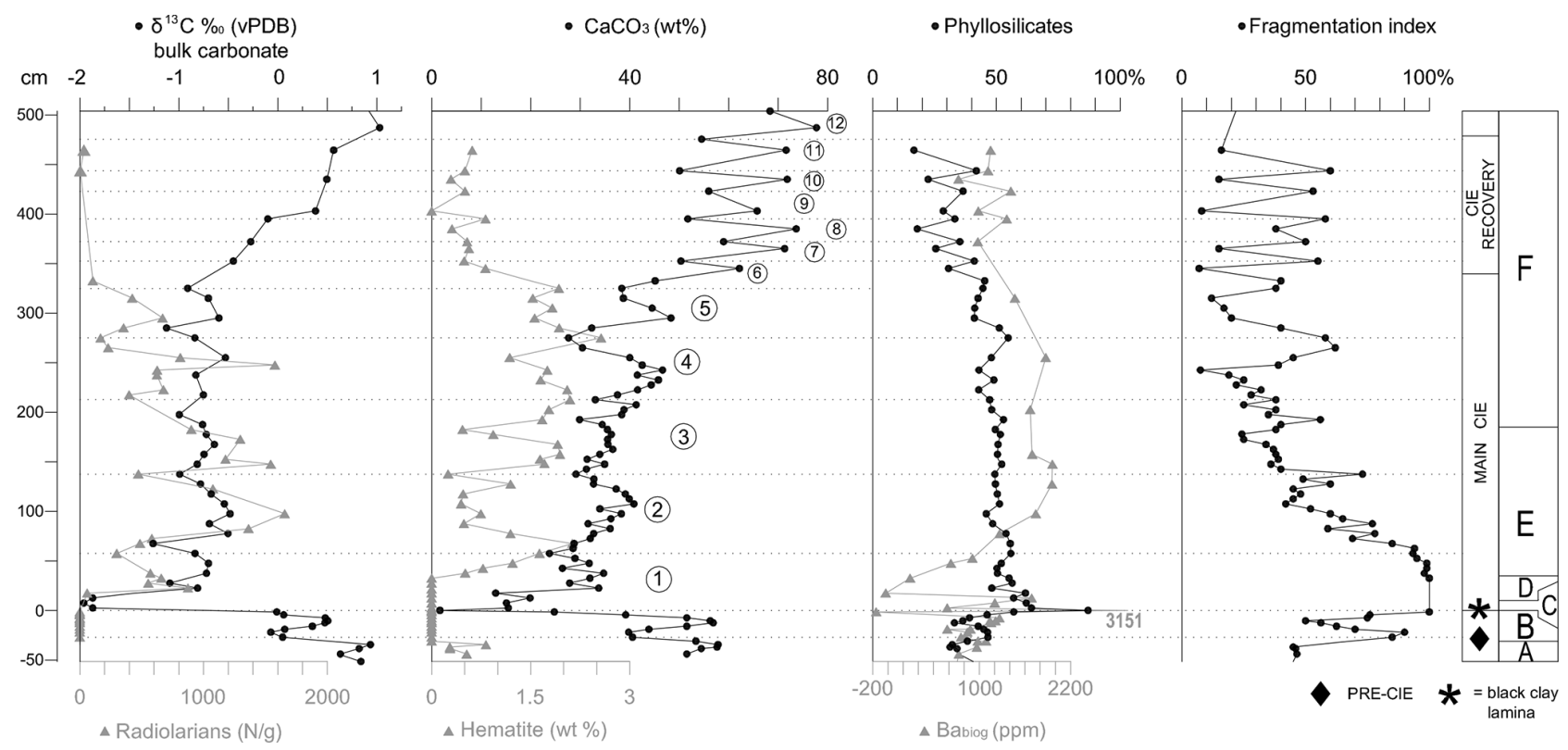

Figure 3. Summary of the main mineralogical, geochemical and cyclostratigraphic features recognized across the Paleocene-Eocene boundary and in the clay marl unit (CMU) of the Forada section and radiolarian abundance plotted against isotopic intervals and recognized benthic foraminiferal assemblages (A to $\mathrm{F}$ ). $\mathrm{N} \mathrm{g}^{-1}$ for the radiolarians refers to the number of radiolarians (>125 $\mu \mathrm{m}$ fraction) per gram of dry sediment. $F$ index from Luciani et al. (2007). VPDB - Vienna Pee Dee belemnite standard. Modified from Giusberti et al. (2007).

The quantitative study of benthic foraminifera was based on representative splits (using a Jones-type micro-splitter, Geneq Inc.) of approximately $200-400$ individuals $>63$ and $<500 \mu \mathrm{m}$ (Table S1 in Supplement). The use of the small size fraction is time-consuming and presents difficulties in taxonomic determination, but we preferred to avoid the loss of small taxa, which are important for paleoecological investigations (e.g., Thomas 1985; Boscolo Galazzo et al., 2013, 


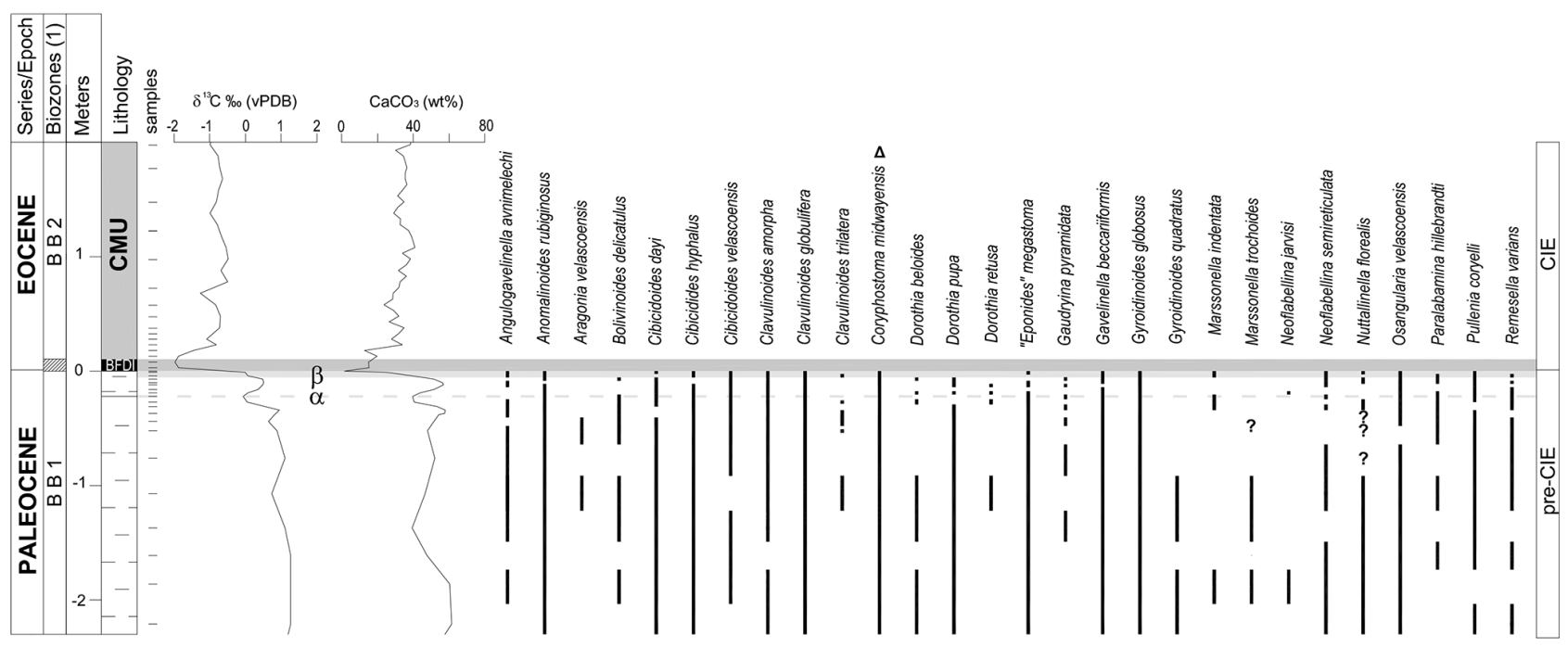

Figure 4. Stratigraphic distribution of benthic foraminiferal extinction taxa (CET) across the Paleocene-Eocene boundary in the Forada section plotted against lithology, ${ }^{13} \mathrm{C}$ bulk record, $\mathrm{CaCO}_{3}$ percentage, and isotopic intervals. Benthic foraminiferal distribution based on data from the $>63 \mu \mathrm{m}$ size integrated with data from $>125 \mu \mathrm{m}$ fraction. The gray bands indicate intervals of carbonate dissolution. Question marks: doubtful identification. Triangle: post BEE occurrence of one specimen of Coryphostoma midwayensis has been recorded in the sample BRI 300 (295 cm above the base of CMU).

2015), especially directly after the BEE, when small species are dominant (Thomas, 1998; Foster et al., 2013). Between 0 and $-222 \mathrm{~cm}$ (uppermost Paleocene), the fraction $\geq 125 \mu \mathrm{m}$ of at least one-fourth of the residue was carefully scanned for large specimens of the extinction taxa, here labeled "cosmopolitan extinction taxa" (CET) (see Thomas, 1998, 2003). These CET records have been treated qualitatively (Fig. 4). The extinction taxa include Anomalinoides rubiginosus, Angulogavelinella avnimelechi, Aragonia velascoensis, Bolivinoides delicatulus, Cibicidoides dayi, C. hyphalus, C. velascoensis, Clavulina amorpha, Clavulinoides trilatera, Clavulinoides globulifera, Coryphostoma midwayensis, Dorothia beloides, D. bulletta, D. pupa, D. retusa, Neoeponides megastoma, Gavelinella beccariiformis, Gyroidinoides globosus, G. quadratus, Marsonella indentata, $\mathrm{Ne}$ oflabellina jarvisi, N. semireticulata, Nuttallinella florealis, Osangularia velascoensis, Paralabamina hillebrandti, Pullenia coryelli, and Remesella varians (e.g., Beckmann, 1960; Von Hillebrandt, 1962; Tjalsma and Lohmann, 1983; Speijer et al., 1996; Thomas, 1998), each of which is present at Forada.

We identified most common taxa at the species level (Table S2). Taxa with high morphological variability and/or variable preservation were identified at generic or higher taxonomic level. Specimens of the most representative taxa were imaged using the SEM at the C.U.G.A.S. (Centro Universitario Grandi Apparecchiature Scientifiche) of Padova University (Plates 1-4). Relative abundances of the taxa and taxon groups, along with faunal indices such as the calcareous / agglutinated ratio, the infaunal/epifaunal ratio, and bi-triserial percentage, were calculated (Figs. 2, 5-7 and S1). The absolute abundance $\left(\mathrm{Ng}^{-1}\right.$ : number of benthic foraminifera per gram of bulk dried sediment) was calculated for both the $\geq 63$ and $\geq 500 \mu \mathrm{m}$ fractions. Faunal diversity indices (species diversity and Fisher- $\alpha$; Fig. 2) were calculated using the PAST package (Hammer et al., 2001). Segments belonging to tubular/branched agglutinated forms (e.g., Rhizammina, Rhabdammina, Bathysiphon) were counted, but they were excluded from calculations because there is no reliable method to convert the abundance of multiple fragments into that of single individuals (Ernst et al., 2006).

We assigned species to epifaunal and infaunal morphotypes by comparing their test morphology to the morphotypes in Corliss (1985), Jones and Charnock (1985), Corliss and Chen (1988), Kaminski and Gradstein (2005), Hayward et al. (2012), and Mancin et al. (2013). However, caution is needed in applying taxonomic uniformitarianism due to our limited knowledge of the biology and ecology of the highly diverse living species. Even for many living species, the relation between test morphology and microhabitat has not been directly observed but is extrapolated from data on other taxa (e.g., Jorissen, 1999). The assignment of modern foraminifera to microhabitats based on their morphology may be accurate in only $75 \%$ of cases (Buzas et al., 1993): comparisons between past and recent environments thus need careful evaluation as well as cross correlation between benthic foraminiferal and other proxy data. The ecology as evaluated from the literature (Table 1) is shown for selected benthic foraminiferal taxa from the PETM interval at Forada. 


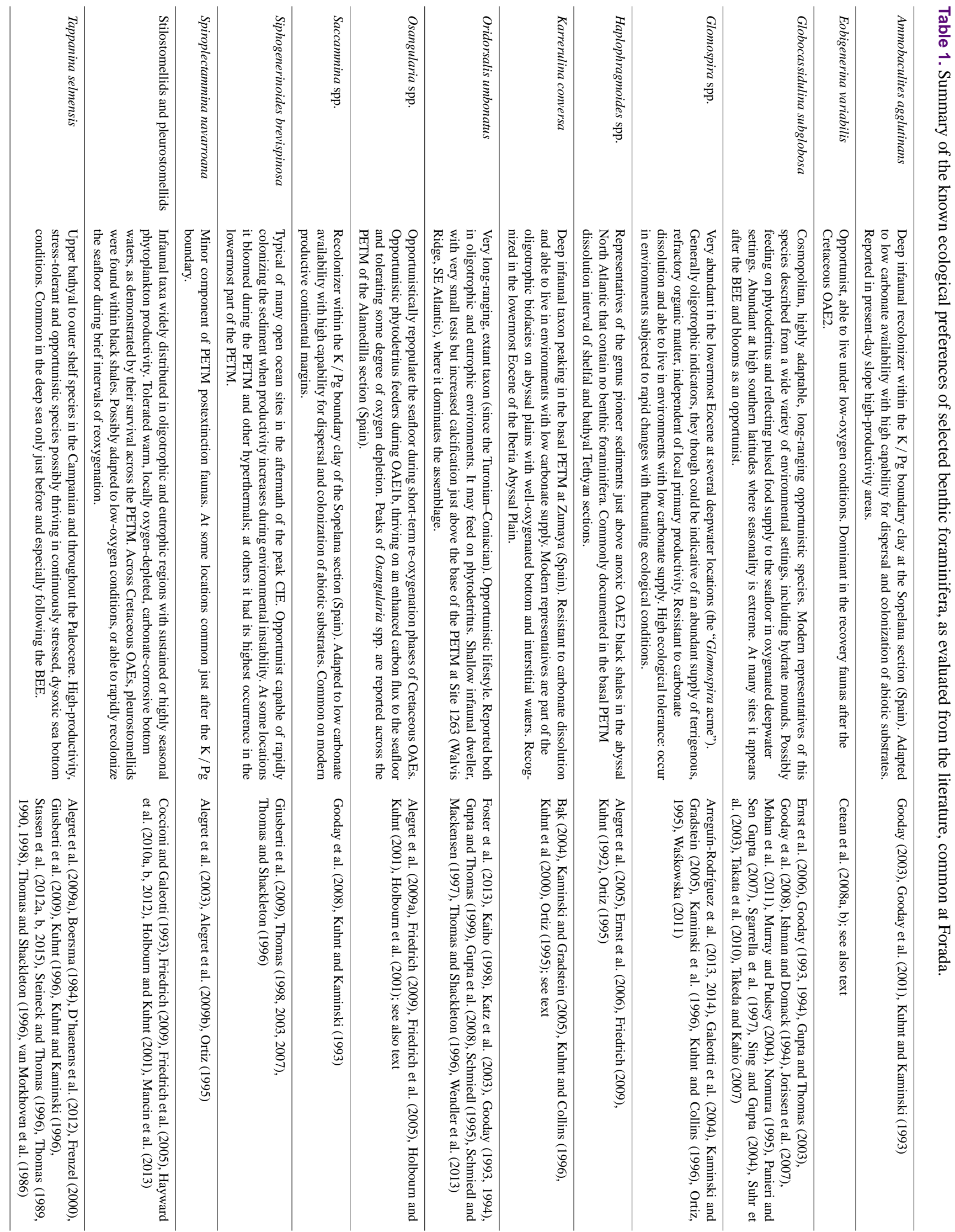




\subsection{Age model}

The age model used for calculating the longevity of benthic foraminiferal assemblages (see below) follows Luciani et al. (2007), with the lower Eocene chronology based on the cyclostratigraphic age model of Giusberti et al. (2007; Fig. 3). The duration of each precessional cycle has been assumed to be $21 \mathrm{kyr}$. Sedimentological and geochemical parameters oscillate cyclically within the main CIE, in at least five complete precessional cycles (Figs. 2, 3). The CIE recovery interval is composed of six distinct, precessional marllimestone couplet cycles (Fig. 3). The recognition of $11 \mathrm{cy}-$ cles in the combined CIE and recovery interval implies an estimate of the total duration of the CIE of ca. $230 \mathrm{kyr}$ (Fig. 3). Giusberti et al. (2007) and Röhl et al. (2007) disagree on the duration of the main CIE and recovery interval $(179 \pm 17$ and $231 \pm 22 \mathrm{kyr}$, respectively). The main difference between these two chronologies is the assignment of different numbers of precessional cycles within the main body and recovery interval (Tipple et al., 2011). A ${ }^{3} \mathrm{He}$-based chronology for Site 1266 (Walvis Ridge) suggests a total PETM duration of $234+48 /-34 \mathrm{kyr}$ (Murphy et al., 2010), in line with the age model of Giusberti et al. (2007).

Lithological cycles have not been firmly identified in the Paleocene part of the section, and sedimentation rates are interpolated between the base of the PETM at $\pm 0 \mathrm{~cm}$ and the lowest occurrence of the calcareous nannofossil Discoaster multiradiatus at ca. $-12.5 \mathrm{~m}$ (Giusberti et al., 2007), using a duration of the time between these events of $1.238 \mathrm{Myr}$ (Westerhold et al., 2007). In this age model, the investigated portion of the Forada section spans ca. $800 \mathrm{kyr}$.

\section{Results}

Benthic foraminiferal assemblages are generally dominated by calcareous hyaline taxa (85-90\%; Fig. 2), but agglutinated taxa significantly increase in abundance within the CMU (25-90\%; Fig. 2). Infaunal taxa strongly dominate the assemblage throughout the studied interval $(\sim 80 \%)$. Faunal diversity is fairly high, particularly in the upper Paleocene (Fig. 2), and preservation is generally moderate, though poor within the lowermost centimeters of the Eocene. Most foraminiferal tests at Forada are recrystallized and either totally or partially filled with calcite.

Composition and abundance of the assemblages change prominently across the ca. $11 \mathrm{~m}$ thick interval investigated (Figs. 2, 5-7) coeval with the geochemical signature of the PETM, and broadly coincident with the main lithological changes. We recognized six successive benthic foraminiferal assemblages (labeled A to F; Figs. 2, 5-8), mainly based on changes in abundance of the taxa listed in Table 1. Assemblages A and B are characteristic of the dominantly reddish calcareous marls mottled by greenish "flames" of the uppermost Paleocene, separated by the thin, barren clay layer from assemblages $\mathrm{C}, \mathrm{D}$ and $\mathrm{E}$, which occur in the first half of the main excursion of the CIE (lowermost Eocene), within the CMU (basal green laminated clays overlain by mottled reddish clays, marly clays and marls). Assemblage F characterizes the marls of the upper half of the CMU, as well as the CIE recovery interval and the overlying post-excursion interval of reddish limestone-marl couplets (Giusberti et al., 2007).

\subsection{Assemblage A: the upper Paleocene fauna}

Assemblage A ( -467.5 to $-37.5 \mathrm{~cm}$, with an estimated duration $>430 \mathrm{kyr}$ ) has a high diversity, with abundant infaunal taxa (ca. $70-80 \%$; Fig. 2). Small bolivinids $(<125 \mu \mathrm{m})$ of the Bolivinoides crenulata group (Plate 3, Figs. 7-9) and smooth-walled Bolivina spp. together comprise 50$60 \%$ of the $>63 \mu \mathrm{m}$ fauna (Fig. 5), with Siphogenerinoides brevispinosa $(\sim 10 \%)$ and other buliminids less common (Figs. 5, 6). Epifaunal morphotypes are mainly represented by small cibicidids (10\%), Anomalinoides spp. (5\%) and Cibicidoides spp. (usually <5\%; Fig. 5). Rare taxa include reussellids, angulogerinids, nodosariids, dentalinids, gyroidinids, valvalabaminids and unilocular hyaline taxa (Fig. S1 in Supplement). Agglutinated taxa are mainly represented by Spiroplectammina spectabilis, Trochamminoides spp., Paratrochamminoides spp., Reophax spp. and Subreophax spp. The Paleocene CET (Plate 1) are not a major component of the assemblage $>63 \mu \mathrm{m}(<10 \%$; Fig. 6), but are common to abundant in the size fraction $>125 \mu \mathrm{m}(>20 \%)$. Many of these have large, heavily calcified tests. The most common taxa include Gavelinella beccariiformis, Pullenia coryelli and Coryphostoma midwayensis (Table S1). CET such as Clavulinoides globulifera, Cibicidoides dayi and Cibicidoides velascoensis are common in the $>500 \mu \mathrm{m}$ size fraction, together with trochamminids and large lituolids (Plate 1, Fig. 19, 6-8; Plate 4, Figs. 7, 8, 14, 20). The latter occur up to the top of the Paleocene, but are absent in the Eocene. At $-261.5 \mathrm{~cm}$, the CET peak at $15 \%$, their maximum abundance in the studied section (Fig. 6). At the same level, peaks of large, stout, heavily calcified taxa (e.g., Cibicidoides and anomalinids) co-occur with agglutinated taxa (Glomospira, Spiroplectammina and Haplophragmoides; Figs. 6, 7), whereas small, thin-walled forms such as bolivinids, Siphogenerinoides brevispinosa and cibicids decline markedly in relative abundance (Figs. 5-7). Faunal density $\left(\mathrm{Ng}^{-1}\right)$, diversity and the percentage abundance of infaunal morphotypes decrease (Fig. 2), as do $\delta^{13} \mathrm{C}$ and $\mathrm{CaCO}_{3} \%$, whereas the planktonic foraminiferal fragmentation index ( $F$ index) increases significantly (Fig. 2). The upper boundary of this assemblage is defined by the increase in abundance of the opportunistic taxa Tappanina selmensis and Siphogenerinoides brevispinosa, marking the onset of Assemblage B. 


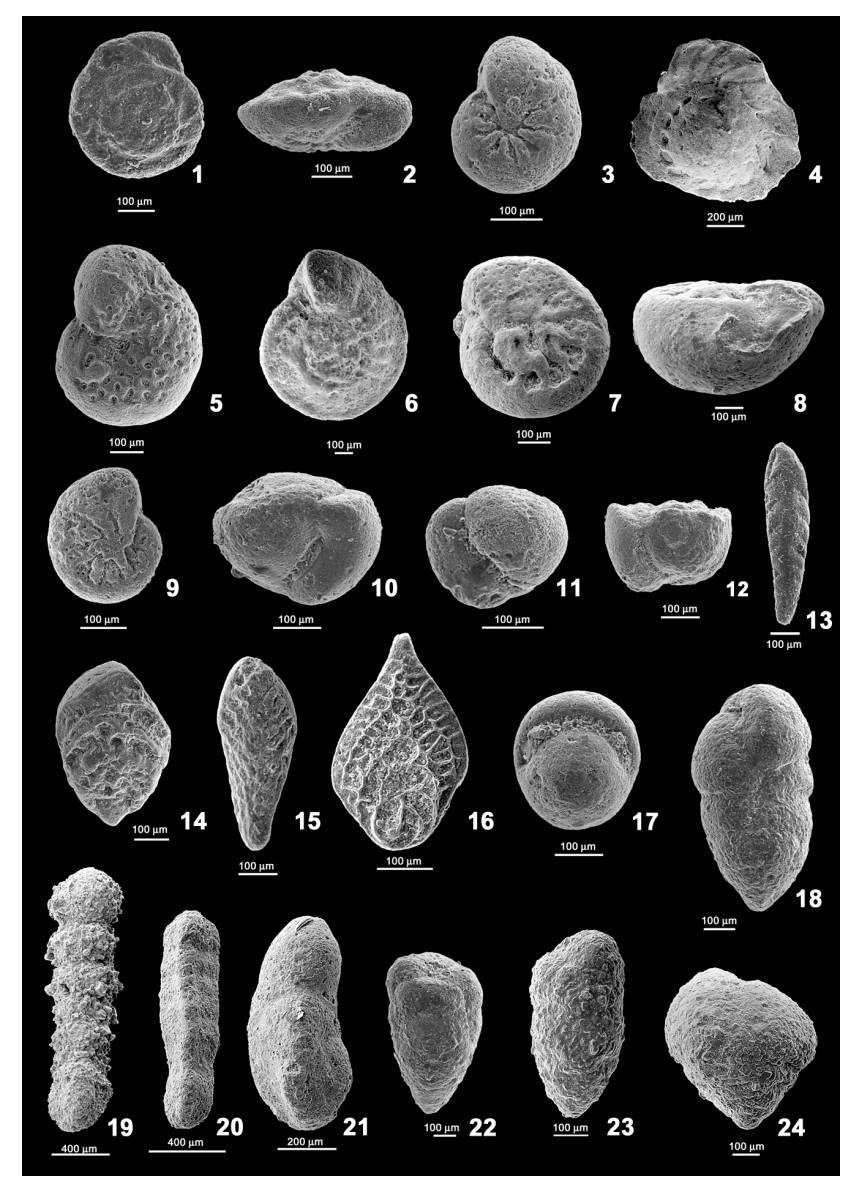

Plate 1. SEM micrographs of the most representative Paleocene cosmopolitan extinction taxa (CET) occurring at Forada. 1. Angulogavelinella avnimelechi, spiral view (BRI-25.5); 2. Angulogavelinella avnimelechi, lateral view (BRI-185.5); 3. Gavelinella beccariiformis, umbilical view (BRI-75); 4. Osangularia velascoensis, spiral view (BRI-50.5); 5. Anomalinoides rubiginosus (BRI-9); 6. Cibicidoides dayi (BRI-37); 7. Cibicidoides velascoensis, spiral view (BRI-75.5); 8. Cibicidoides velascoensis, lateral view (BRI-135.5); 9. Cibicidoides hyphalus (BRI-50.5); 10. "Neoeponides" megastoma (BRI-135); 11. Gyroidinoides globosus (BRI-50.5); 12. Gyroidinoides quadratus (BRI-185.5); 13. Coryphostoma midwayensis (BRI-50.5); 14. Aragonia velascoensis (BRI-50.5); 15. Bolivinoides delicatulus (BRI-135.5); 16. Neoflabellina semireticulata (BRI-365); 17. Pullenia coryelli (BRI-50.5); 18. Remesella varians (BRI-310.5); 19. Clavulinoides globulifera (BRI-25.5); 20. Clavulinoides trilatera (BRI-33); 21. Clavulinoides amorpha; 22. Marssonella indentata (BRI-25.5); 23. Dorothia beloides (BRI-260); 24. Dorothia pupa (BRI-105).

\subsection{Assemblage B: the pre-CIE Paleocene fauna}

Assemblage B occurs at -31 to $0 \mathrm{~cm}$, estimated duration $\sim 34$ kyr. At about $-20 \mathrm{~cm}$ the lithology shifts from reddish to greenish marls with Zoophycos and Chondrites (intervals Pa I and II of Giusberti et al., 2007). In this assemblage, Siphogenerinoides brevispinosa and Tappanina sel- mensis increase in relative abundance compared to Assemblage A (> $10 \%$ at $\sim-27$ and $-12 \mathrm{~cm}$; Figs. 6, 7). Between the two peaks of $S$. brevispinosa (at about $\sim-20 \mathrm{~cm}$; Figs. 6 , 7 ), there is a transient negative carbon isotope excursion of about $1 \%$, a drop in $\mathrm{CaCO}_{3}$ from 60 to $40 \%$, a decline in the coarse fraction to $2 \%$, and a peak in the $F$ index (85$90 \%$; Figs. 2, 3). Small and thin-walled taxa such as bolivinids, cibicidids and $S$. brevispinosa decreases markedly in relative abundance, whereas big, heavily calcified taxa (e.g., Cosmopolitan Extinction Taxa, Cibicidoides spp., Nuttallides truempyi) and agglutinated forms increase (Figs. 57). In addition, faunal density drops, as does the percentage of infaunal taxa (from 90 to $50 \%$ ), and diversity increases (Fig. 2). From $-4.5 \mathrm{~cm}$ upwards, the preservation of benthic foraminifera deteriorates, while the $F$ index reaches $100 \%$ (Figs. 2, 3). At $-1.5 \mathrm{~cm}$ preservation worsens and most bitriserial taxa decline in abundance drastically, whereas benthic foraminiferal absolute abundance and $\mathrm{CaCO}_{3} \%$ both decrease (Fig. 2). Faunal diversity peaks, while anomalinids, Cibicidoides spp., N. truempyi, O. umbonatus, and agglutinated forms increase markedly in relative abundance (Figs. 2, $5,6)$. In the uppermost Paleocene sample, we see the highest occurrence of most CET (Figs. 4, 6). Few CET (e.g., Aragonia velascoensis) disappear below this sample (Fig. 4). These are generally rare, occurring discontinuously throughout the Paleocene, even in large samples of residue $>125 \mu \mathrm{m}$ (Fig. 4). The uppermost occurrence of the CET defines the upper boundary of this assemblage, at the base of the black clay layer (Figs. 4, 6).

\subsection{The black clay}

The lowermost Eocene is a thin, black clay layer ( 0 to $+0.3 \mathrm{~cm}$ ), slightly enriched in organic carbon, and carbonatefree (Giusberti et al., 2007; Figs. 3, 8). This clay marks the base of the CMU, and contains a few specimens only, agglutinated benthic foraminifera of the genera Haplophragmoides and Recurvoides (10 specimens in $22 \mathrm{~g}$ washed sediment). It probably was deposited over less than a millennium, in view of its small thickness and place within the precessionally paced cycles in the PETM.

\subsection{Assemblage C: basal CIE agglutinated fauna}

We label BFDI (benthic foraminiferal dissolution interval) the lowermost Eocene interval (lowermost $10 \mathrm{~cm}$ of laminated green clays of $\mathrm{CMU}$; estimated duration $3.5 \mathrm{kyr}$ ) with low $\mathrm{CaCO}_{3}$ wt $\%(\sim 15 \%)$, and the most negative $\delta^{13} \mathrm{C}$ values in bulk carbonate $(-2 \%$ ). Assemblage $\mathrm{C}$ is dominated by agglutinated taxa (about $90 \%$; Fig. 2) with badly preserved and deformed tests. Tests of calcareous-hyaline forms are rare, partially dissolved and fragmented. Assemblage C has minimum values of faunal density $(<5)$, diversity, and wt $\%$ coarse fraction (Fig. 2). Infaunal morphotypes have their lowest abundance (ca. 36\%; Figs. 2, 6). Agglutinated 


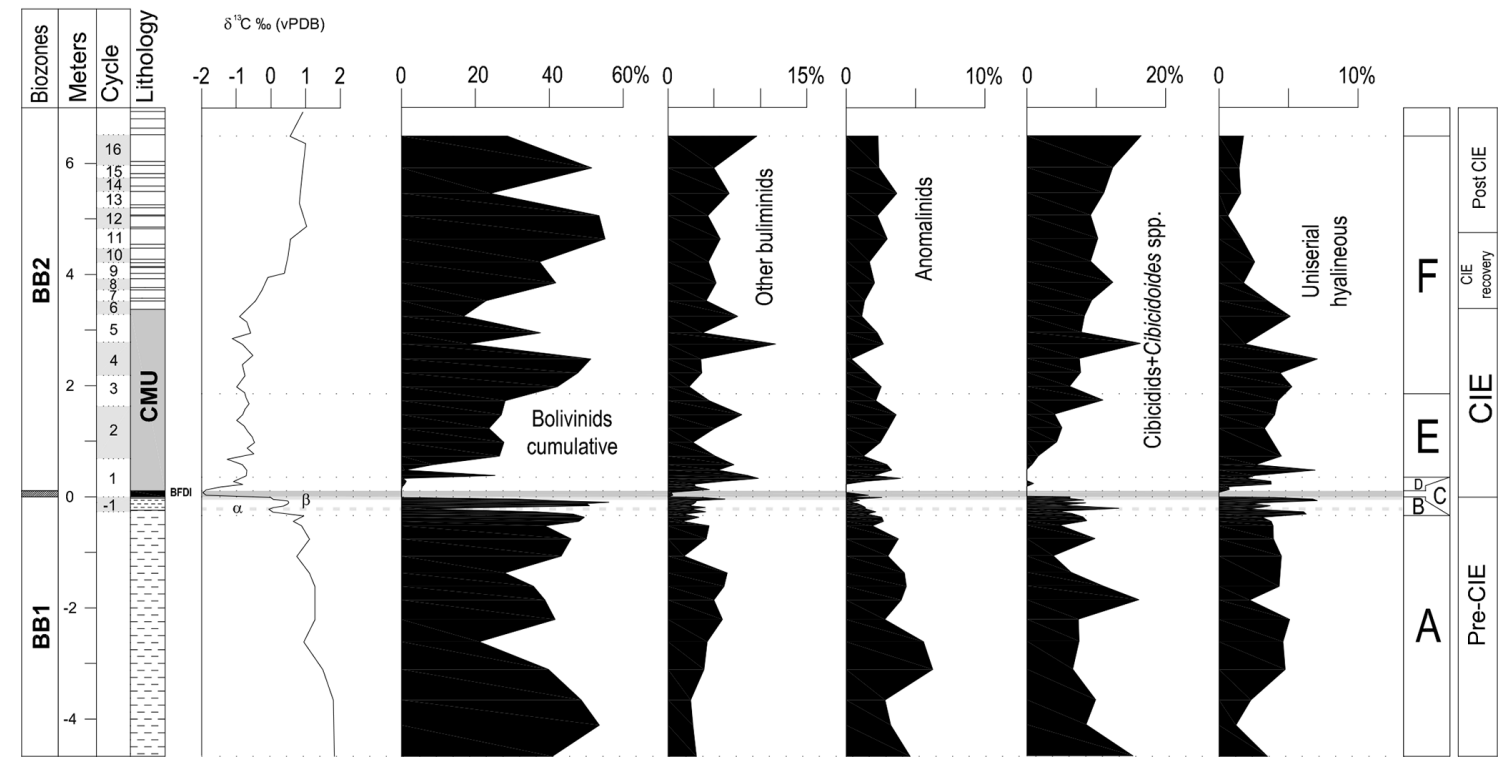

Figure 5. Relative abundance of the most abundant benthic foraminiferal taxa across the PETM at Forada plotted against biostratigraphy, precessional cycles, lithology, $\delta^{13} \mathrm{C}$ bulk record, recognized benthic foraminiferal assemblages (A to F) and isotopic intervals. Benthic foraminiferal biozonation after Berggren and Miller (1989). The gray bands indicate intervals of carbonate dissolution. $\alpha$ : pre-CIE dissolution; $\beta$ : burndown layer; BFDI: benthic foraminiferal dissolution interval. The "other buliminids" group includes only representatives of the families Buliminidae, Buliminellidae and Turrilinidae (Bulimina, Buliminella, Quadratobuliminella, Sitella and Turrilina).

foraminifera are mainly represented by Eobigenerina variabilis (25\%; Plate 1, Figs. 2, 3), Haplophragmoides spp. (20\%), Glomospira spp. (15\%), Saccamina spp. (10\%) and Spiroplectammina navarroana ( $~ 8 \%$; Plate 2, Fig. 6). In its upper part, Assemblage $\mathrm{C}$ has high abundances of Karrerulina spp. ( 20\%; K. conversa; Plate 2, Fig. 4) and Ammobaculites agglutinans (10\%; Plate 2, Fig. 1). The latter taxa occur at relatively high abundance in the overlying assemblages, up to $\sim+50-70 \mathrm{~cm}$ (Figs. 6, 7). The upper boundary of this assemblage is defined by the first substantial recovery of hyaline taxa $(>50 \%)$.

\subsection{Assemblage D: lowermost CIE fauna}

In Assemblage D $(+10$ to $+35 \mathrm{~cm}$, lithologically characterized by laminated green clays; estimated duration $\sim 9 \mathrm{kyr}$ ), calcareous-hyaline forms are consistently present and badly preserved, with dominant taxa having dwarfed and thinwalled tests, e.g., Globocassidulina subglobosa (25\%), Tappanina selmensis (20\%), and Osangularia spp. ( 11\%; Figs. 6, 7; Plate 2, Figs. 13-16). A specific assignment of basal PETM osangulariids at Forada is not possible because of their very small size and poor state of preservation. From $+30 \mathrm{~cm}$ upwards, relative abundances of $G$. subglobosa and Osangularia spp. drastically decline, whereas $T$. selmensis reaches its maximum abundance (ca. 33\%; Figs. 6, 7). Minor components are the "other buliminids" group (up to $10 \%$ at the top of the assemblage; see Figs. 5 and 5 - related caption), Pleurostomella spp., Oridorsalis umbonatus, anoma- linids and stilostomellids (Figs. 5, 6 and S1). Agglutinated forms remain abundant, up to $50 \%$. At $+20 \mathrm{~cm}$, calcified radiolarians become abundant, dominating the microfossil association up to $+2 \mathrm{~m}$ above the base of CMU (Luciani et al., 2007; Figs. 3, 8). Within the interval of Assemblage D, $\delta^{13} \mathrm{C}$ shifts from -2 to $-1 \%$, and the $\mathrm{CaCO}_{3} \mathrm{wt} \%$ recovers to $\sim 40 \%$, despite strong dilution with terrigenous sediments (Fig. 3). The upper boundary of this assemblage is defined by the consistent decrease in T. selmensis (to $<5 \%$ ).

\subsection{Assemblage E: main CIE fauna I}

In this interval $(+35$ to $+185 \mathrm{~cm}$; lithologically characterized by green and reddish clays and marls; estimated duration ca. $42 \mathrm{kyr}$ ) benthic foraminiferal preservation improves, and calcareous-hyaline forms dominate the assemblages again (Fig. 2). Siphogenerinoides brevispinosa is consistently present again, with two peaks up to $20 \%$ (Figs. 6 , 7). Pleurostomella spp. increase to up to $>10 \%$, and Bolivinoides crenulata and smooth-walled Bolivina spp. to up to 30-40\% (Figs. 5, 6). Calcareous-hyaline epifaunals such as cibicids and anomalinids reappear at $<5 \%$ (Fig. 5). Faunal density and diversity gradually increase upwards, whereas agglutinated taxa markedly decrease in abundance $(<20 \%)$ at $\sim 70 \mathrm{~cm}$ (Fig. 2). The upper boundary of this assemblage is defined by the marked drop in relative abundance of $S$. brevispinosa (to $<5 \%$ ). 

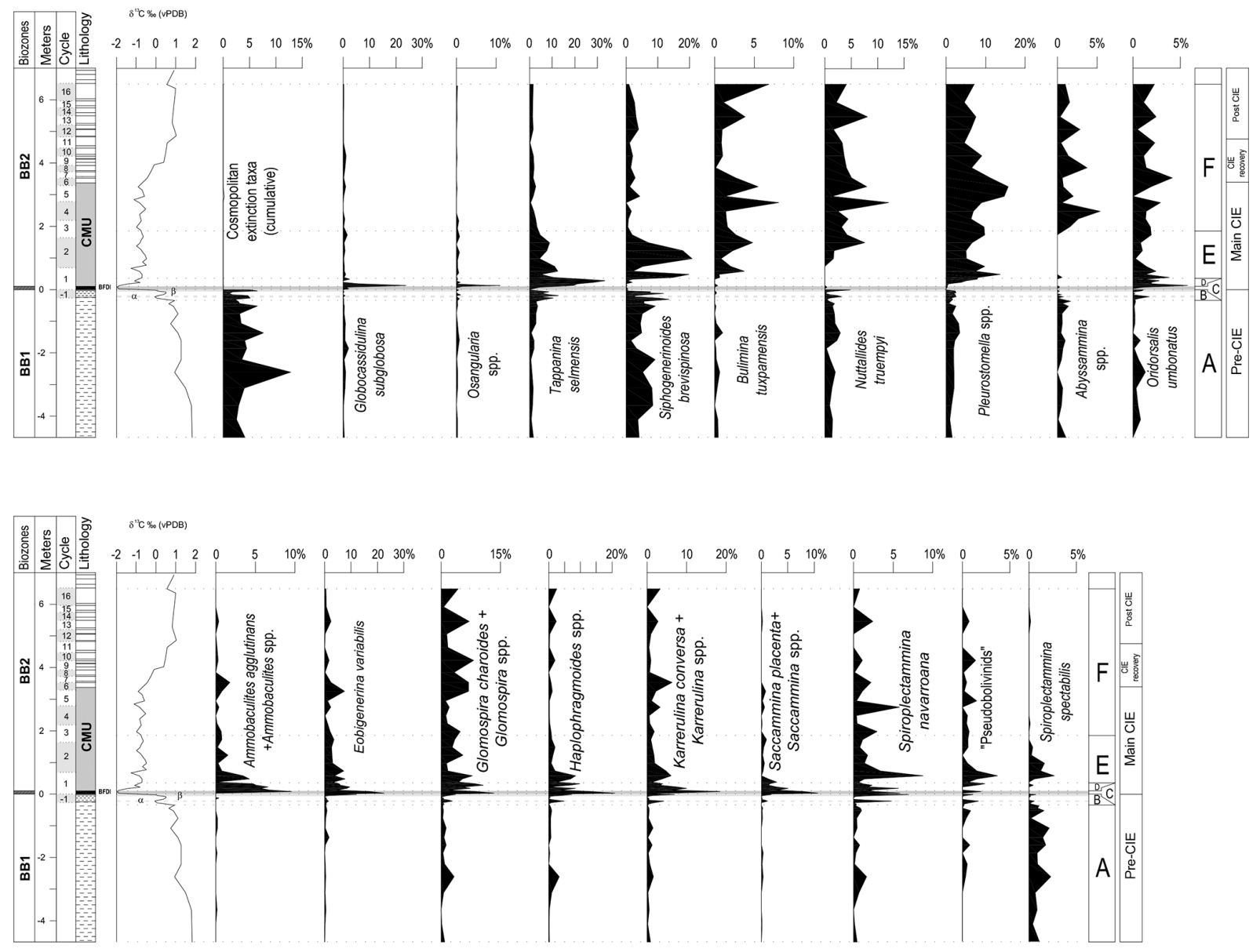

Figure 6. Relative abundance of selected benthic foraminifera across the PETM at Forada plotted against biostratigraphy, precessional cycles, lithology, $\delta^{13} \mathrm{C}$ bulk record, recognized benthic foraminiferal assemblages (A to $\mathrm{F}$ ) and isotopic intervals. Benthic foraminiferal biozonation after Berggren and Miller (1989). The gray bands indicate intervals of carbonate dissolution. $\alpha$ : pre-CIE dissolution; $\beta$ : burndown layer; BFDI: benthic foraminiferal dissolution interval.

\subsection{Assemblage F: main CIE fauna II, CIE recovery and post CIE fauna}

Assemblage F characterizes the upper half of the CMU (reddish marls), from about $+185 \mathrm{~cm}$ up to its top $(+337.5 \mathrm{~cm})$, and the overlying interval (red marly limestone couplets) up to $+649 \mathrm{~cm}$; estimated total duration $>281 \mathrm{kyr}$ ). The relative abundance of Siphogenerinoides brevispinosa is low (<5\%), whereas Bulimina tuxpamensis and Nuttallides truempyi increase in abundance, respectively to 5 and $10 \%$, and show cyclical variations in relative abundance (Figs. 6, 7). Pleurostomellids $(\sim 10 \%)$, the "other buliminids" group ( $\sim 10 \%$; Fig. 5), cibicids $(\sim 10 \%)$, Oridorsalis umbonatus $(\sim 5 \%)$, stilostomellids $(\sim 5 \%)$ and Abyssammina spp. $(\sim 5 \%)$ are common (Figs. 5, 6). Relative abundance of infaunal taxa (mostly bolivinids) and faunal density $\left(\mathrm{Ng}^{-1}\right)$ returns to Paleocene values (75-80\%; Fig. 2). Diversity increases (simple diversity up to 60, Fisher- $\alpha$ diversity up to 20; Fig. 2) but remains lower than in the Paleocene. All faunal indices show cyclical variation (Fig. 2), as do the rel- ative abundance of benthic foraminifera as well as planktic foraminiferal and calcareous nannofossil assemblages (Agnini et al., 2007; Luciani et al., 2007). In the lower third of the interval in which this assemblage occurs, just above the CMU (ca. $+337.5 \mathrm{~cm}$ ), the relative and absolute abundance of radiolarians decrease markedly and agglutinated taxa such as Glomospira spp., Eobigenerina variabilis and Karrerulina spp. slightly increase in relative abundance $(\sim+2-3 \%)$ (Figs. 2, 3, 6, 7).

\section{Discussion}

\subsection{Paleodepth of the Forada section}

Based on benthic foraminifera in the $>125 \mu \mathrm{m}$ size fraction, Giusberti et al. (2007) suggested a paleodepth between 600 and $1000 \mathrm{~m}$ for the Forada section. Our data on the $>63 \mu \mathrm{m}$ size fraction suggest a somewhat greater paleodepth, i.e., upper lower bathyal, between 1000 and $1500 \mathrm{~m}$ (van Morkhoven et al., 1986). Representatives of the bathyal and 


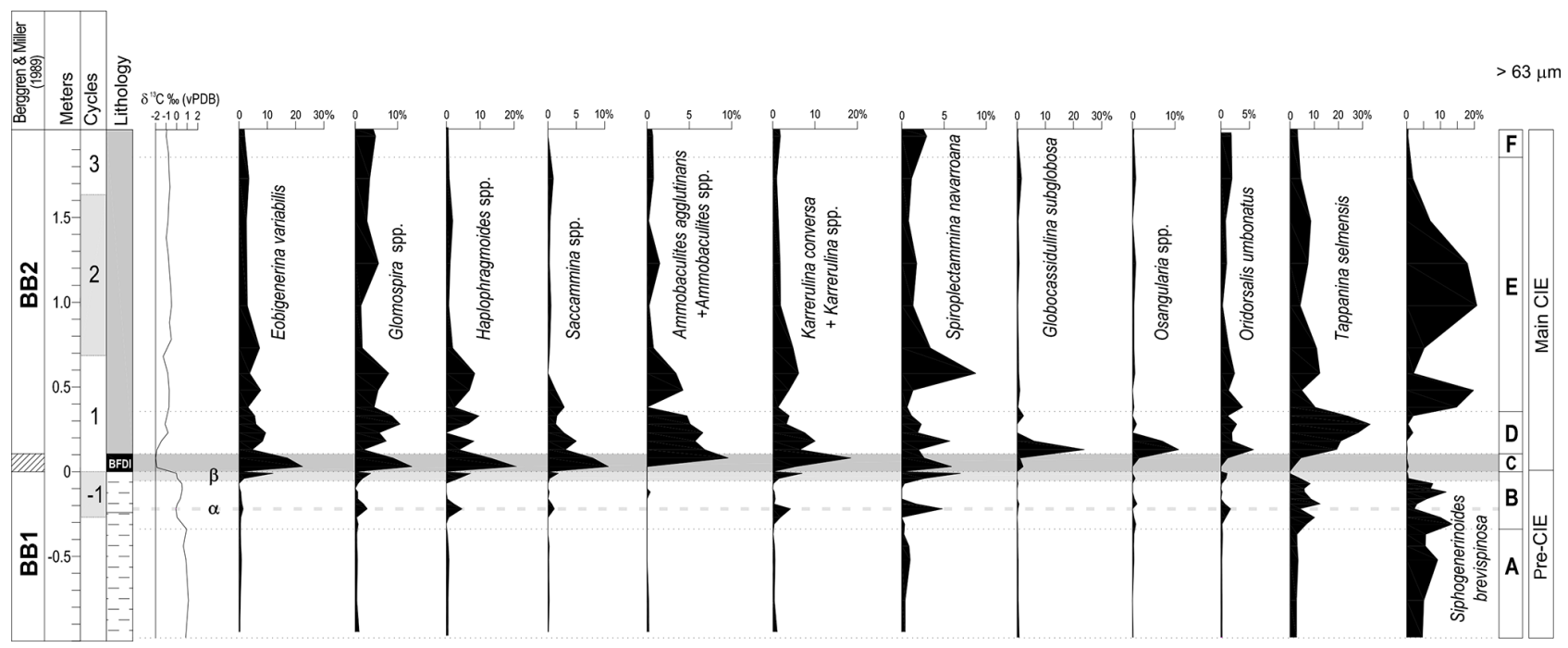

Figure 7. Enlargement of the interval from -1 to $+2 \mathrm{~m}$ across the Paleocene-Eocene boundary at Forada showing the relative abundance of selected benthic foraminifera plotted against biostratigraphy, precessional cycles, lithology, $\delta^{13} \mathrm{C}$ bulk record, recognized benthic foraminiferal assemblages (A to F) and isotopic intervals. Benthic foraminiferal biozonation after Berggren and Miller (1989). The gray bands indicate intervals of carbonate dissolution. $\alpha$ : pre-CIE dissolution interval; $\beta$ : burndown layer; BFDI: benthic foraminiferal dissolution interval.

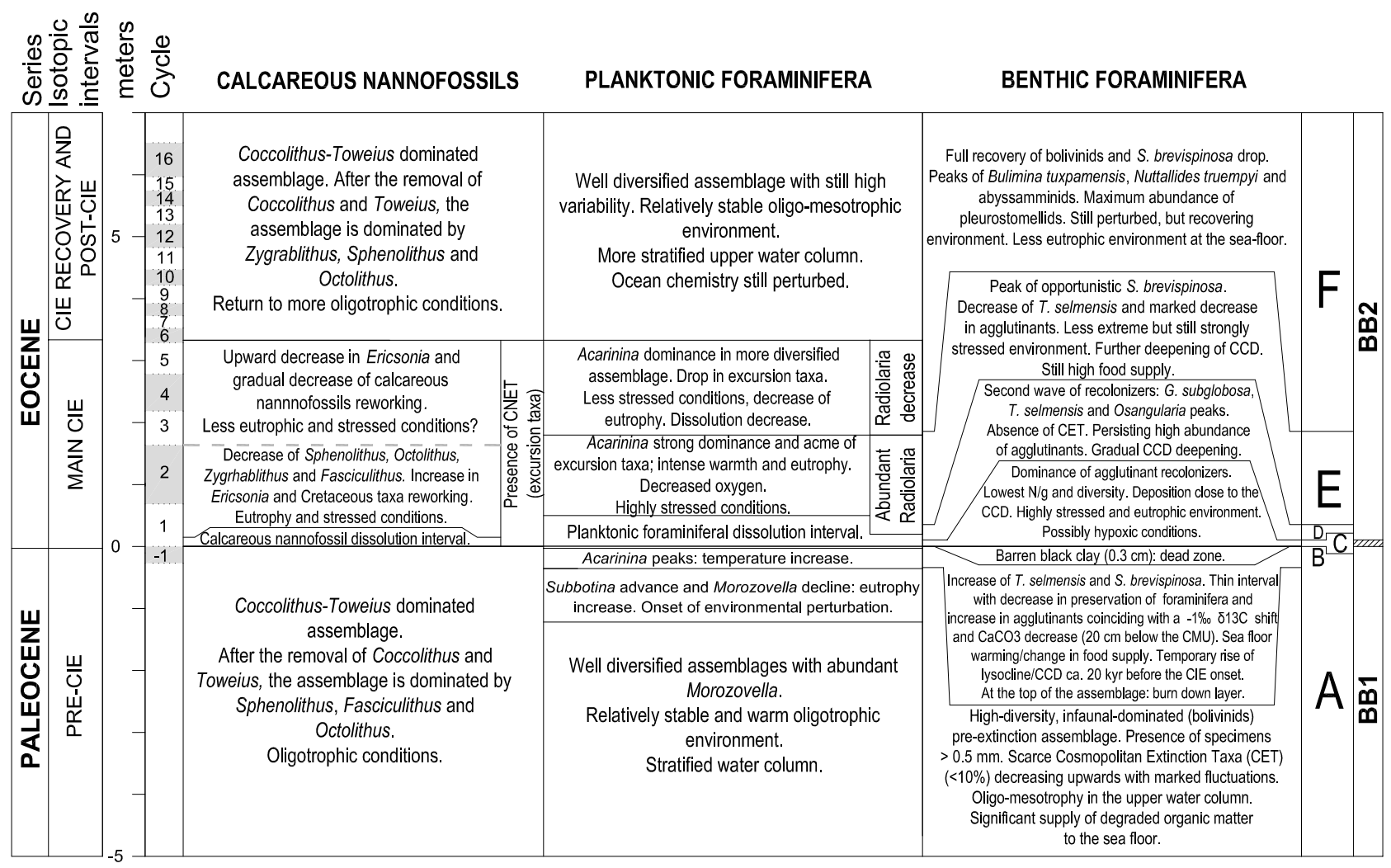

Figure 8. Summary of main calcareous plankton (calcareous nannofossils and planktonic foraminifera) and benthic foraminiferal events and inferred environmental conditions (from Agnini et al., 2007; Luciani et al., 2007 and present work), isotopic intervals, thickness, precessional cycles and benthic foraminiferal assemblages (A to F) recognized in this work. The stratigraphic intervals containing assemblages A and $\mathrm{B}, \mathrm{C}$, and D to $\mathrm{F}$ are considered as pre-extinction, extinction and repopulation intervals, respectively. Benthic foraminiferal zonation after Berggren and Miller (1989). CNET: calcareous nannofossil excursion taxa (see Agnini et al., 2007). 


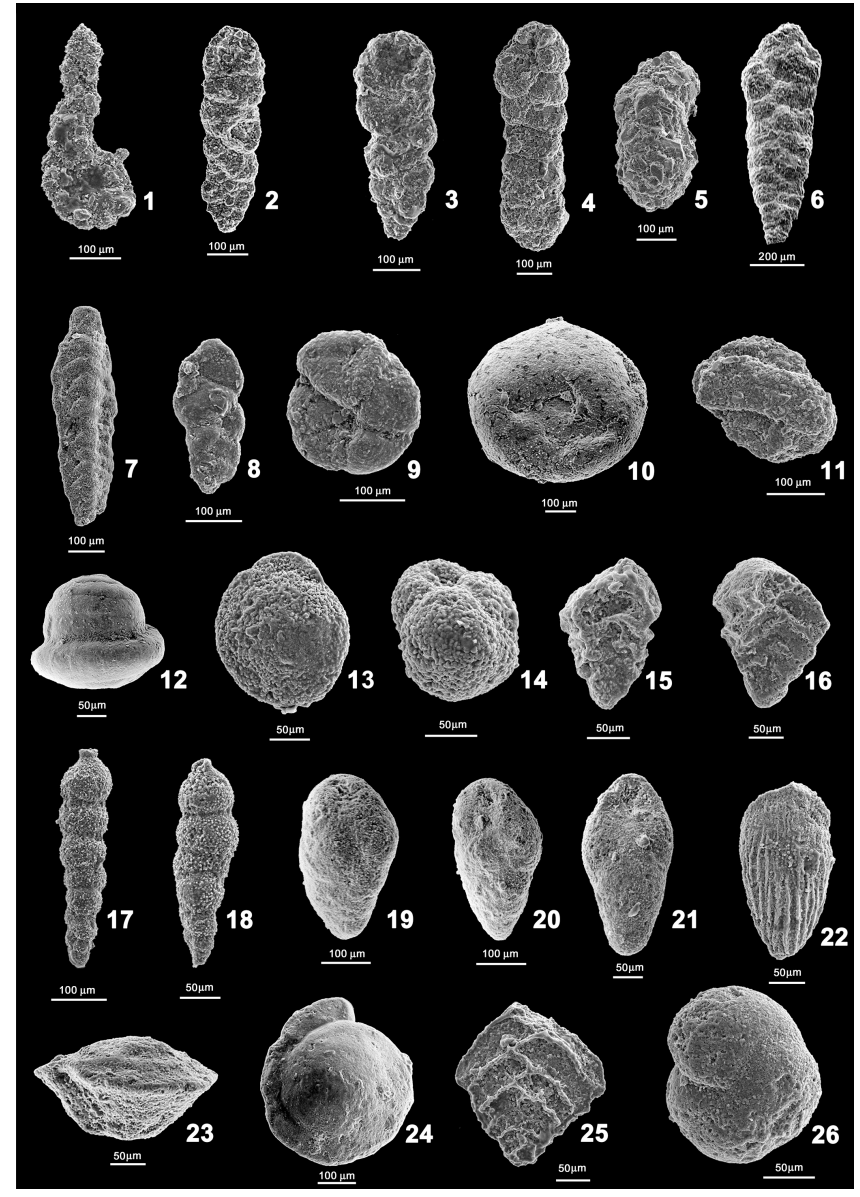

Plate 2. SEM micrographs of the most representative species of the Eocene postextinction faunas occurring at Forada. 1. Ammobaculites agglutinans (BRI+10); 2. Eobigenerina variabilis $(\mathrm{BRI}+50) ; 3$. Eobigenerina variabilis $(\mathrm{BRI}+50) ; 4$. Karrerulina conversa (BRI+50); 5. Karrerulina horrida (BRI-25.5); 6. Spiroplectammina navarroana (BRI-33/7); 7. Spiroplectammina spectabilis (BRI+50); 8. Rashnovammina munda (BRI-50.5); 9. Haplophragmoides cf. kirki. (BRI+5); 10. Saccammina placenta (BRI-25.5); 11. Glomospira irregularis (BRI+35); 12. Glomospira charoides (BRI-75.5); 13. Osangularia sp. (BRI+15); 14. Globocassidulina subglobosa (BRI+15); 15. Tappanina selmensis (BRI+15); 16. Tappanina selmensis (BRI-9); 17. Siphogenerinoides brevispinosa (BRI-11); 18. Siphogenerinoides brevispinosa (BRI-365); 19. Bulimina tuxpamensis (BRI+150); 20. Bulimina tuxpamensis (BRI+150); 21. Pleurostomella sp. (BRI+150); 22. Bolivina sp. costate (BRI+385); 23. Nuttallides truempyi (BRI+150); 24. Oridorsalis umbonatus (BRI-135.5); 25. Aragonia aragonensis (BRI-105); 26. Abyssammina poagi (TAL7B).

abyssal Velasco-type fauna (Berggren and Aubert, 1975), such as Aragonia velascoensis, Cibicidoides velascoensis, Gyroidinoides globosus, Nuttallides truempyi, Nuttallinella florealis, Osangularia velascoensis and Gavelinella beccariiformis are common at Forada. The faunas across the uppermost PETM interval and higher are similar to the PETM

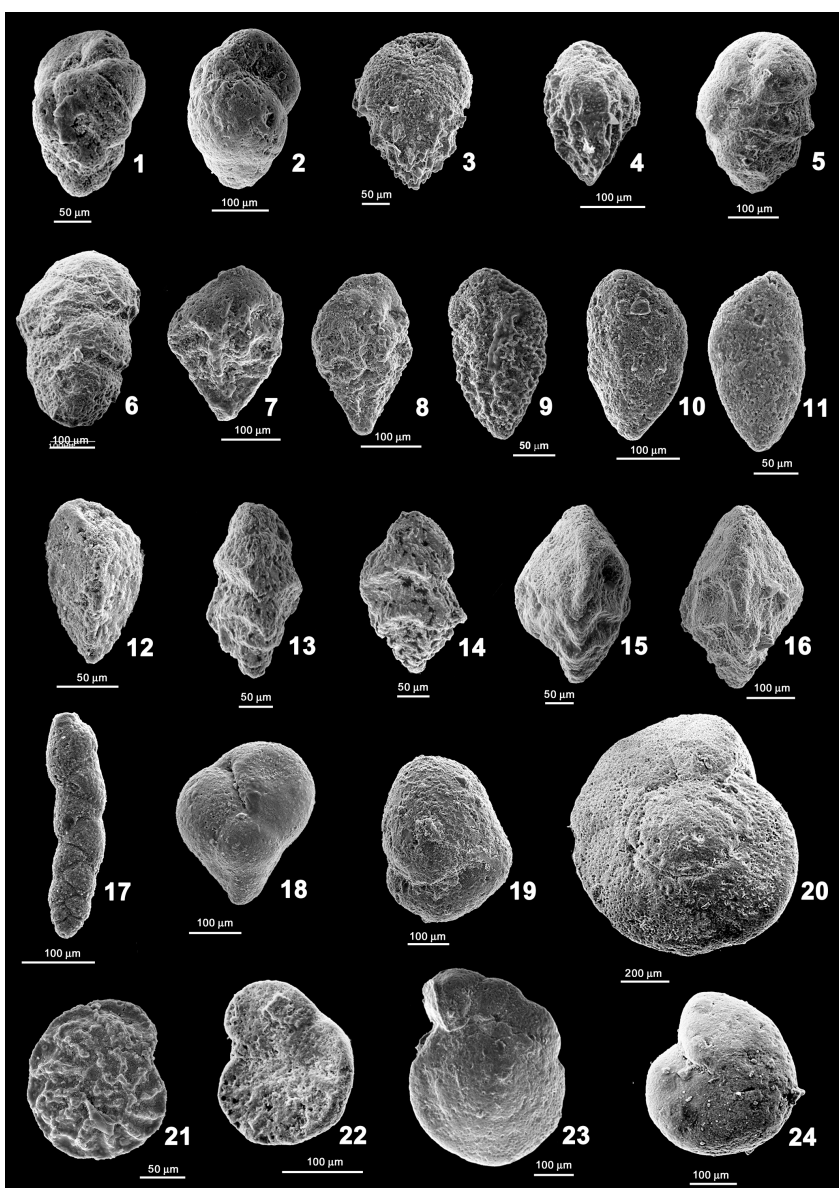

Plate 3. SEM micrographs of the most representative taxa of the upper Paleocene-lower Eocene of the Forada section. 1. Quadratobuliminella pyramidalis (BRI-75.5); 2. Buliminella grata (BRI-591); 3. Bulimina midwayensis (BRI+35); 4. Bulimina alazanensis (BRI +150); 5, 6. Bulimina trinitatensis (BRI-9); 7. Bolivinoides crenulata (BRI-9); 8. Bolivinoides crenulata (BRI-25.5); 9. Bolivinoides floridana (BRI-410); 10 Bolivina sp. smooth (BRI-410); 11. Bolivina sp. smooth (BRI-410); 12. Reussella sp. (BRI-365); 13. Angulogerina muralis (BRI-75.5); 14. Angulogerina muralis (BRI-75.5); 15. Angulogerina? sp. (BRI-9); 16. Angulogerina? sp. (BRI-35.5); 17. Rectobulimina carpentierae (BRI-466); 18. Allomorphina trochoides (BRI-25.5); 19. Quadrimorphina allomorphinoides (TAL 7B); 20. Cibicidoides eocaenus (BRI-9); 21. Anomalinoides sp. 2 (BRI-135); 22. Cibicides sp. (BRI-591); 23. Cibicidoides praemundulus (BRI+150); 24. Nonion havanense (BRI-591).

fauna in the upper abyssal Alamedilla section (southern Spain; Alegret et al., 2009a) and at Walvis Ridge at $1500 \mathrm{~m}$ paleodepth (Thomas and Shackleton, 1996; Thomas, 1998). Abyssammina spp. and Nuttallides truempyi (upper depth limit at 1000 and $300 \mathrm{~m}$, respectively; Van Morkhoven et al., 1986; Speijer and Schmitz, 1998) increase in abundance by more than a factor of 2 during the PETM at Forada, as typical for PETM deep-sea benthic foraminiferal records (e.g., Thomas, 1998, 2007; Thomas and Shackleton, 1996; Alegret 


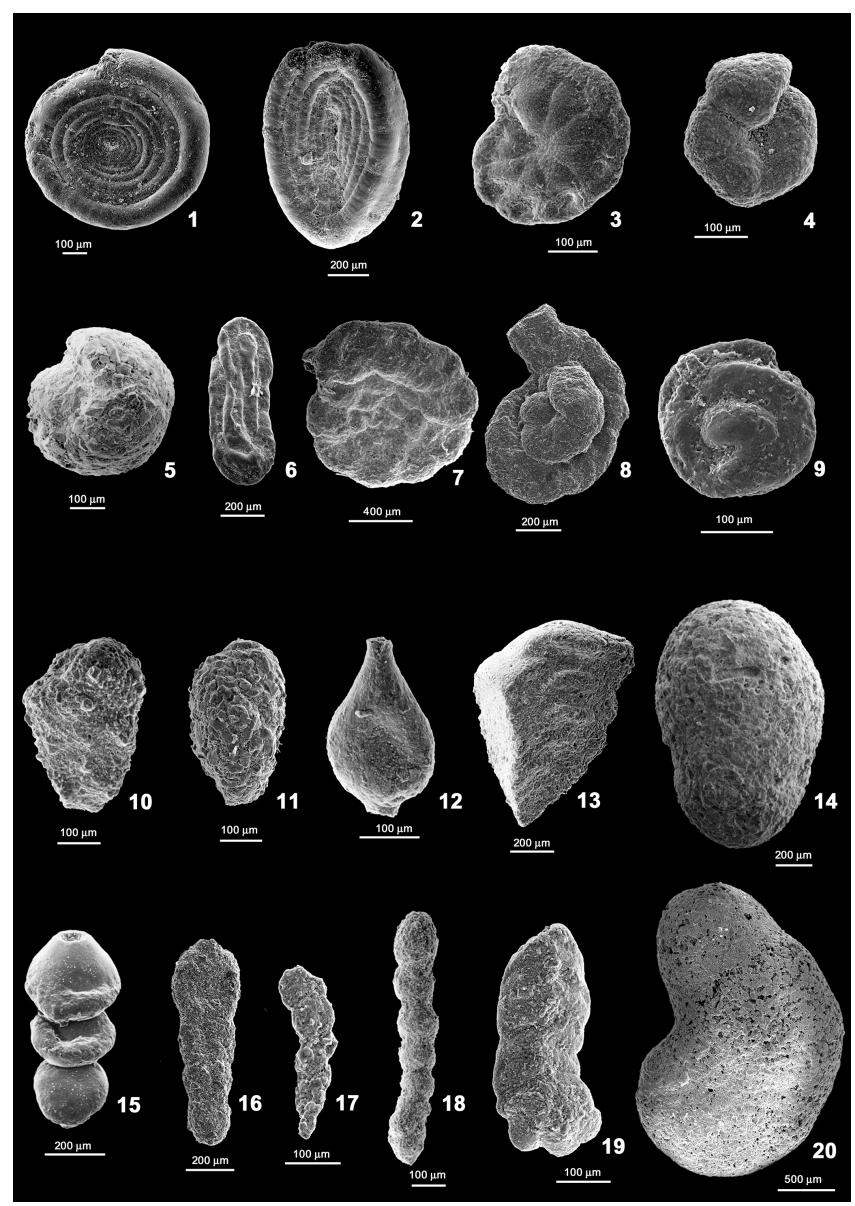

Plate 4. SEM micrographs of some taxa of the upper Paleocenelower Eocene of the Forada section. 1. Ammodiscus cretaceus (BRI-29.5); 2. Ammodiscus peruvianus (BRI-9); 3. Haplophragmoides walteri (BRI-75.5); 4. Haplophragmoides horridus (BRI +35); 5. Recurvoides sp. (BRI -33/-37); 6. Glomospira serpens (BRI-260); 7. Trochamminoides proteus (BRI-25.5); 8. Paratrochamminoides heteromorphus (BRI+40); 9. Glomospira cf. gordialis (BRI +35); 10. Gaudryina sp. (BRI +15); 11. Karrerulina coniformis (BRI-135); 12. Caudammina ovuloides (BRI-260); 13. Gaudryina pyramidata (BRI-17.5); 14. big-sized lituolid, apertural view (BRI-9); 15. Hormosina velascoensis (BRI-33/37); 16. Pseudonodosinella troyeri (BRI-260); 17. "Pseudobolivina" sp. 2 in Galeotti et al. (2004) (BRI+35); 18. Pseudoclavulina trinitatensis (BRI+150); 19. Spiroplectammina spectabilis (BRI-50.5); 20. big-sized lituolid, lateral view (BRI-9).

et al., 2009a, 2010; Giusberti et al., 2009). In these deliberations we excluded the bolivinids, because we consider that their high abundance is due to the "delta-depression effect" (see below).

\subsection{Environmental reconstruction during the late Paleocene}

\subsubsection{The Belluno Basin Paleocene deep-sea environment (Assemblage $A$ )}

Throughout most of the investigated section, infaunals strongly dominate over epifaunals, mainly due to the high abundances of bolivinids (Figs. 2, 5). Such dominance of bolivinids is common in lower and middle Eocene hemipelagic Scaglia sediments in the Belluno Basin (Agnini et al., 2009; Boscolo Galazzo et al., 2013). Presently, bolivinids are common along continental margins, and at bathyal depths, at the interception of the oxygen minimum zone (OMZ) with the seafloor, typically between 200 and $1000 \mathrm{~m}$ in modern oceans (Levin, 2003). High abundances of bolivinids commonly correlate with high organic matter flux and/or oxygen depletion (e.g., Murray, 1991; Gooday, 1994; Bernhard and Sen Gupta, 1999; Schmiedl et al., 2000; Thomas et al., 2000; Jorissen et al., 1995, 2007; Thomas, 2007). We see high abundances of such taxa typically at greater depths than usual in regions with significant organic matter input from rivers, the so-called "delta-depression effect" first described in the Gulf of Mexico (Pflum and Frerichs, 1976; Jorissen et al., 2007). Such lateral inputs of organic matter thus result in (partial) decoupling between the food supply to the benthos and local primary productivity (e.g., Fontanier et al., 2005; Arndt et al., 2013).

At Forada, there is neither geochemical nor sedimentological evidence for persistent suboxic conditions at the seafloor (Giusberti et al., 2007), and the high benthic foraminiferal faunal diversity likewise does not indicate low-oxygen conditions. The upper Paleocene calcareous plankton is dominated by morozovellids, indicating oligotrophic surface water conditions (Luciani et al., 2007; Fig. 8). The calcareous nannofossil assemblage is dominated by the generalist taxa Toweius and Coccolithus, with high percentages of Sphenolithus and Fasciculithus (Agnini et al., 2007; Fig. 8), supporting that surface waters were oligotrophic. We thus think that environments in the Belluno Basin, close to a continental margin (Agnini et al., 2007), were characterized by the delta-depression effect, in which hemipelagic sedimentation incorporated significant laterally transported terrigenous organic matter to serve as food for the benthos (e.g., Fontanier et al., 2005; Arndt et al., 2013).

The occurrence of large, epifaunal $(>500 \mu \mathrm{m})$ species (Assemblage A and B) has been related to an optimum food supply, but also to very low food supply, since a lack of food keeps individuals from reproducing successfully and leads to continued test growth (Boltovskoy et al., 1991; Thomas and Gooday, 1996).

Overall, Assemblage A indicates oligo-mesotrophic surface waters, with bolivinids probably exploiting refractory, laterally advected organic matter. The high faunal diversity suggests that seasonal to periodical increases in primary pro- 
ductivity may have occurred (e.g., Gooday, 2003; Fontanier et al., 2006a, b, 2014), allowing a species-rich, highly diverse infauna and epifauna to inhabit the seafloor, and co-occur with the bolivinids in the sedimentary record.

At Forada, the relative abundance of Paleocene CET is low (average < $10 \%$; Fig. 6), due to the large number of Bolivinacea dominating the fine size fraction used for this study $(>63 \mu \mathrm{m})$. Many CET are epifaunal morphotypes, commonly larger than $125 \mu \mathrm{m}$, as also noted elsewhere (e.g., Giusberti et al., 2009). Similarly low percentages (12-15\%) of CET have been recorded in Scaglia sediments of the Contessa section (Giusberti et al., 2009) and at ODP Site 690 by Thomas (2003), where infaunal morphotypes (buliminids and uniserial calcareous taxa) are abundant in the $>63 \mu \mathrm{m}$ fraction.

\subsubsection{The precursor warming event (Assemblage B)}

The onset of Assemblage B, about $34 \mathrm{kyr}$ before the onset of the CIE $(\sim-30 \mathrm{~cm})$, is marked by increase in relative abundance of opportunistic taxa such as Tappanina selmensis and Siphogenerinoides brevispinosa (Figs. 6, 7; Table 1). The arrival of Tappanina selmensis, an upper bathyal to outer shelf species in the Maastrichtian (Frenzel, 2000), at greater depths might indicate warming of deep waters before the beginning of the PETM, as also reflected in the migration of warm-water planktonic species to high southern latitudes (Thomas and Shackleton, 1996; Table 1). The benthic foraminiferal changes roughly coincided with a significant increase in acarininids \% (planktonic foraminifera, $>50 \%$ ), likely indicating warming of surface waters (Luciani et al., 2007; Fig. 8). The foraminiferal assemblages hence suggest warming throughout the water column and increased surface nutrient availability and deepwater food availability, whereas no changes in productivity in calcareous nannofossils are recorded (Agnini et al., 2007; Luciani et al., 2007; Fig. 8). The foraminiferal evidence for warming is associated with an increase in $\delta \mathrm{D}_{n \text {-alkanes and }} \mathrm{TEX}_{86}$ values (Fig. 9), suggesting increased aridity and sea surface temperature prior to the onset of the CIE (Tipple et al., 2011).

Multiple proxies thus indicate that climatic and oceanographic conditions started to change $\sim 30 \mathrm{kyr}$ before the onset of the CIE, pointing to a PETM precursor event, reflected by a $<5 \mathrm{~cm}$ thick dissolution interval at $\sim-22 \mathrm{~cm}$, coinciding with a negative shift in bulk $\delta^{13} \mathrm{C}(-1 \%$; Figs. 2, 3). Within this interval, dissolution-sensitive benthic foraminifera (e.g., S. brevispinosa and small bolivinids) markedly decrease in abundance, while more robust and agglutinated taxa increase (Figs. 2, 5-8), as does the $F$ index of planktic foraminifera (to $\sim 85-90 \%$; Luciani et al., 2007; Fig. 3). This dissolution level may thus reflect a brief episode of rising lysocline/CCD $(<5 \mathrm{kyr})$ in response to a precursory emission of isotopically light carbon (Bowen et al., 2015). Similar precursor events have been observed worldwide (e.g., Sluijs et al., 2007b, 2011; Secord et al., 2010;
Kraus et al., 2013; Garel et al., 2013; Bornemann et al., 2014; Bowen et al., 2015), indicating that disturbance of the global carbon cycle started before the PETM, as potentially also reflected in the occurrence of hyperthermals in the Paleocene (Thomas et al., 2000; Cramer et al., 2003; Coccioni et al., 2012).

At the top of Assemblage B (uppermost $4.5 \mathrm{~cm}$ ), just prior to the onset of the CIE, carbonate preservation declined markedly, as reflected in $\mathrm{F}$ index, $\mathrm{CaCO}_{3} \%$, and foraminiferal preservation. In this interval, representing the "burndown" layer (BL; e.g., Thomas and Shackleton, 1996; Thomas et al., 1999; Giusberti et al., 2007; Figs. 4, 7, 8), CET remained present. Dissolution in the upper BL removed most thin, dissolution-prone calcareous tests (e.g., Siphogenerinoides brevispinosa and small bolivinids), concentrating the more heavily calcified and the agglutinated taxa (including CET; Figs. 5-7). Benthic foraminiferal assemblages in the topmost Paleocene at Forada thus cannot be interpreted with confidence due to the severe dissolution.

\subsection{Climate and marine life during the PETM}

\subsubsection{The black clay: a desert below the CCD}

This very thin, carbonate-free interval is somewhat enigmatic. The virtually barren sediment may have been deposited during the maximum rise of the $\mathrm{CCD}$, under environmental conditions so unfavorable that benthic life was excluded, a "dead zone" (sensu Harries and Kauffman, 1990) during the earliest phase of the PETM. Geochemical redox indices in the black clay and the underlying and overlying samples suggest persistently oxygenated bottom waters (Giusberti et al., 2007), but may reflect diagenesis during reoxygenation of bottom waters after a short period of anoxia, as commonly observed for Mediterranean sapropels (Higgs et al., 1994; van Santvoort et al., 1996). The presence of the thin black clay without microfossils is thus highly suggestive of a brief pulse of anoxia, as supported by a single peak value of organic carbon ( $0.6 \mathrm{wt} \%$; Giusberti et al., 2007). The high value of biogenic barium ( $3151 \mathrm{ppm}$ ) in the black clay (Fig. 3), despite the fact that barite is generally not preserved under anoxic conditions (Paytan and Griffith, 2007; Paytan et al., 2007), may represent reprecipitation at the oxic-anoxic sediment interface after dissolution under anoxic conditions (Giusberti et al., 2007), and/or high rates of organic remineralization in the water column, during which the barite forms (Ma et al., 2014).

\subsubsection{The early peak PETM (assemblages $C$ and D)}

The $10 \mathrm{~cm}$ of sediment directly overlying the PaleoceneEocene boundary (i.e., the base of the CIE; Figs. 7, 8) was deposited in strongly $\mathrm{CaCO}_{3}$-corrosive waters, below the lysocline and close to or below the CCD. The rapid rise of the $\mathrm{CCD} /$ lysocline during the PETM is a predicted consequence 


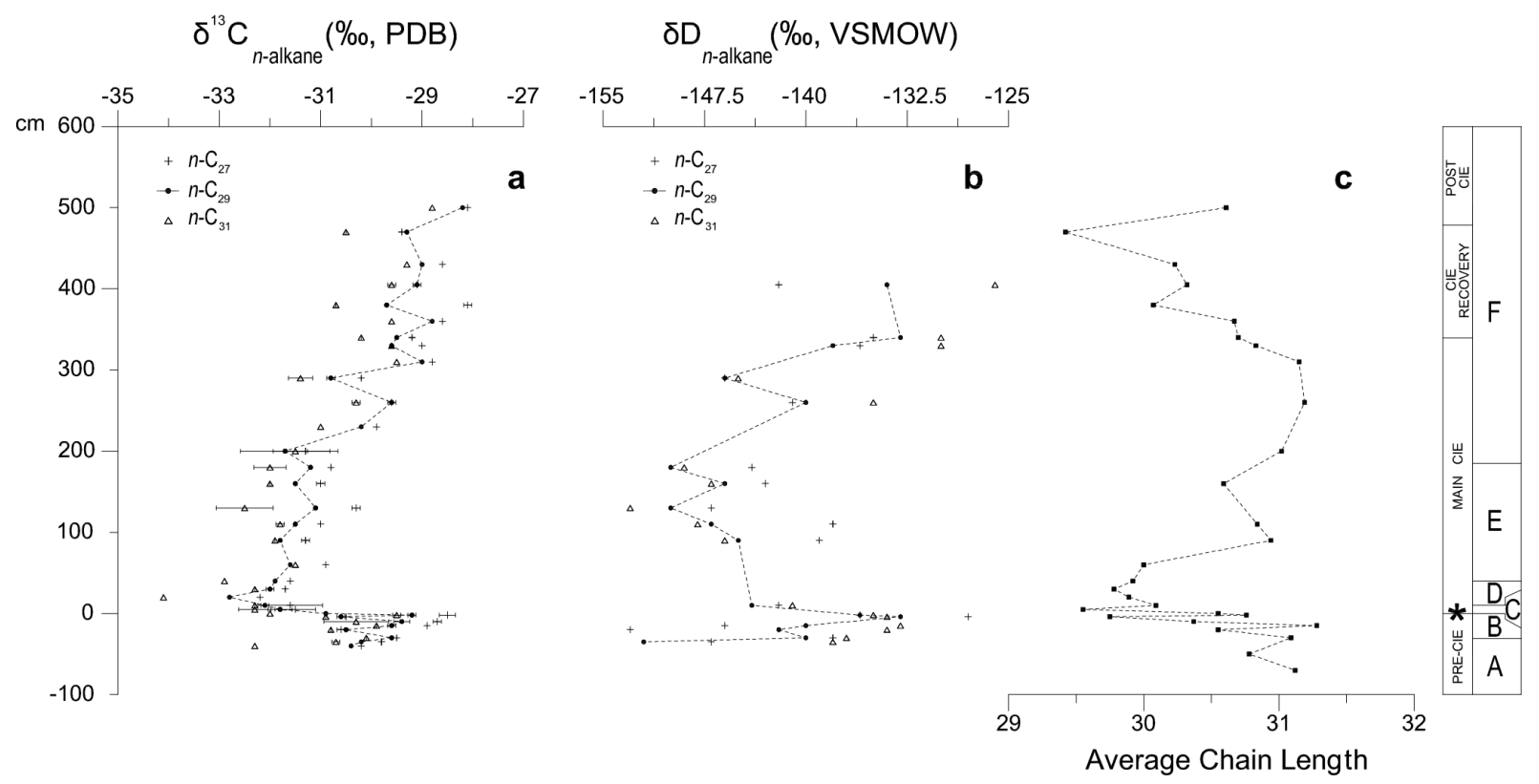

Figure 9. Stable carbon isotope ratios of higher plant $n$-alkanes (a), stable hydrogen isotope ratios of higher plant $n$-alkanes (b) with higher plant average chain length values (c) for Forada PETM plotted against isotopic intervals and recognized benthic foraminiferal assemblages (A to F). Terrestrial higher plant $n-\mathrm{C} 27, n-\mathrm{C} 29$, and $n-\mathrm{C} 31 \delta \mathrm{D}$ values are shown as crosses, closed circles, and triangles, respectively. Redrawn from data of Tipple et al. (2011).

of massive input of carbon $\left(\mathrm{CO}_{2}\right.$ or $\left.\mathrm{CH}_{4}\right)$ in the oceanatmosphere system on a millennial timescale (e.g., Dickens et al., 1997; Thomas, 1998; Zachos et al., 2005; Zeebe et al., 2009, 2014; Hönisch et al., 2012). The carbonate dissolution at Forada is consistent with observations at many other deepsea sites (e.g., Schmitz et al., 1997; Thomas, 1998; Zachos et al., 2005; Kelly et al., 2010). The benthic foraminiferal extinction event (BEE) at Forada (i.e., corresponding to the BB1-BB2 zonal boundary of Berggren and Miller, 1989) occurs within this $10 \mathrm{~cm}$ thick interval, between the top of the CET-bearing burndown layer and the base of Assemblage D, where benthic calcareous taxa reappear (Figs. 4, 7, 8). The concentration of CET in the burndown layer, and the reappearance of calcareous hyaline taxa only $10 \mathrm{~cm}$ above the onset of the PETM at Forada, confirms that the CET extinction occurred over $3.5 \mathrm{kyr}$ or less in the central-western Tethys, similar to evaluations of this timing from carbon cycle modeling (Zeebe et al., 2014).

Sediment just above the black clay, reflecting a first slight deepening of the CCD, contains a low-diversity fauna of mostly agglutinated, dwarfed (close to $63 \mu \mathrm{m}$ in diameter) benthic foraminifera as well as calcareous nannofossils with signs of dissolution, with planktic foraminifera virtually absent (Agnini et al., 2007; Luciani et al., 2007; Fig. 8). This first wave of benthic pioneers recolonized the seafloor during the peak $\mathrm{CIE}$, in $\mathrm{CaCO}_{3}$-undersaturated waters, and reflects a highly stressed environment (Assemblage C; Figs. 68). Among the pioneers, Eobigenerina variabilis is peculiar of the PETM of the Forada section (Figs. 6, 7). Eobi- generina is a recently erected genus in the Textulariopsidae, including non-calcareous species previously assigned to Bigenerina (Cetean et al., 2011), and it is known to behave opportunistically during Cretaceous Oceanic Anoxic Event 2 (OAE2; Table 1). A major component of the upper part of Assemblage C is Karrerulina conversa (Fig. 7). The species dominates the lowermost Eocene deposits in the Polish Carpathians (Bakk, 2004), commonly occurring in the Paleocene-Eocene of the central North Sea and Labrador margin, and in Morocco (Kaminski and Gradstein, 2005). Modern Karrerulina (e.g., K. apicularis $=$ K. conversa) lives in oligotrophic abyssal plains, with well-oxygenated bottom and interstitial waters (Table 1). However, the test morphology of Karrerulina, combined with its abundant occurrence in the doubtless stressed environment of the basal PETM at Forada and Zumaia (Table 1), suggests that this genus may also act opportunistically.

After ca. $4 \mathrm{kyr}$, a further deepening of CCD allowed a consistent increase in abundance of benthic calcareous taxa (ca. $50 \%$; Assemblage D; Fig. 2), coinciding with the lowermost recovery of bulk carbonate $\delta^{13} \mathrm{C}$ values, from -2 to $-1 \%$ o (Giusberti et al., 2007; Tipple et al., 2011; Fig. 7). These calcareous recolonizers included dwarfed and thin-walled forms of G. subglobosa, Tappanina selmensis, Osangularia spp. and Oridorsalis umbonatus (Figs. 6, 7). A similar peak in small Osangularia also occurs in the basal PETM at the Contessa section, as documented for the first time in the present paper (Fig. S2). Representatives of the genus Osangularia (Osangularia spp.) behaved opportunistically in the PETM 
of the Tethyan Alamedilla section (Alegret et al., 2009a). Moreover, Boscolo Galazzo et al. (2013) found small-size Osangularia within organic-rich levels immediately following the Middle Eocene Climatic Optimum in the Alano section (in northeastern Italy). During the Cretaceous OAEs, Osangularia spp. opportunistically repopulated the seafloor during short-term re-oxygenation phases (see references in Table 1). Although Osangularia is generally referred to as preferring stable, well-oxygenated environments (e.g., Murray, 2006; Alegret et al., 2003), we suggest that some extinct species of this genus could actually behave as opportunists and recolonizers.

Assemblage D contains almost equal abundances of calcareous and agglutinated taxa, indicating that factors other than bottom water $\mathrm{CaCO}_{3}$ concentration were controlling faunal variability within this assemblage (Figs. 6, 7). Possibly, strongly enhanced runoff and sediment delivery can explain the abundance of agglutinated taxa (40-60\%), such as Glomospira spp. (e.g., Arreguín-Rodríguez et al., 2013, 2014), above the first $10 \mathrm{~cm}$ of the CMU. We thus recognize a rapid succession of recolonizer taxa during the first $12 \mathrm{kyr}$ of the CIE (assemblages C-D). The small size of both the agglutinated and hyaline recolonizers is indicative of r-strategist species which reproduce quickly and can thus quickly repopulate stressed environments, as soon as conditions improve slightly (e.g., Koutsoukos et al., 1990; Thomas, 2003). The rapid pace at which different populations of recolonizers succeeded each other indicates a highly unstable environment, with marked fluctuations in the amount, timing and quality of the food reaching the seafloor. Sediment deposition during this interval may have occurred in rapid pulses, e.g., following intense rainstorms, carrying refractory organic matter to the deep-sea environment. Pauses between events may have allowed the benthic foraminifera to recolonize the sediment, profiting from the abundance of food. This is consistent with calcareous nannofossil assemblages showing an increase in $\mathrm{Er}$ icsonia and declines in abundance of Sphenolithus, Octolithus, Zygrhablithus and Fasciculithus, indicating an unstable and nutrient-rich upper water column (Agnini et al., 2007; Fig. 8). Archaeal biomarkers show a large influx of terrestrial, soil-derived organic matter (branched and isoprenoid tetraethers, or BIT index) from the onset of the PETM up to $\sim+10 \mathrm{~cm}$ (Tipple et al., 2011). Higher plant $n$-alkane average chain length (ACL) decreased immediately after the onset of the CIE, consistent with increased humidity (Fig. 9; Tipple et al., 2011). The abundance of the clay mineral chlorite indicates enhanced physical erosion (Robert and Kennett, 1994) during deposition of the lower $50 \mathrm{~cm}$ of the CMU, rapidly decreasing upward (Fig. S3).

The greenish marly clays containing assemblages $\mathrm{C}$ and $\mathrm{D}$ show primary lamination, indicating that macrobenthic invertebrates were absent, as at the Dee and Mead Stream sections (New Zealand; Nicolo et al., 2010) and Zumaya (Spain; Rodríguez-Tovar et al., 2011). The presence of ben- thic foraminifera, however, indicates that bottom and pore waters were not permanently anoxic. Pore waters may have become dysoxic periodically due to high temperatures, decomposing organic matter and possibly enhanced water column stratification, leading to the absence of metazoans and stressed benthic foraminiferal assemblages. Low-pH seafloor conditions may have also played a significant role in excluding macrobenthic fauna in this early phase of PETM at Forada. Deep-sea animals are highly sensitive to even modest but rapid pH changes (Seibel and Walsh, 2001), which are harmful even for infaunal deep-sea communities (Barry et al., 2004).

\subsubsection{The core of the CIE and recovery (assemblages E, F)}

The benthic foraminiferal assemblage changes significantly from Assemblage D to Assemblage E, coinciding with the gradual reappearing of mottling (as thin reddish "flames" in the green sediment). Bolivinids return as a major faunal component $(50 \%)$, and agglutinated taxa decrease in abundance. Peaks of tapered elongate calcareous forms, including Siphogenerinoides brevispinosa, the "other buliminids" group, pleurostomellids and stilostomellids, replace the recolonizers (Figs. 5, 6). These groups could have been functioned as opportunistic taxa, able to flourish when food supply was periodically high (e.g., Table 1). Coinciding with Assemblage E, planktic foraminifera return to be a significant component of the microfossil assemblage (e.g., Luciani et al., 2007; Fig. 8), while radiolarians remain abundant throughout the CMU (Giusberti et al., 2007; Luciani et al., 2007). The planktic foraminiferal assemblage is dominated by acarinininids, with a double peak of the excursion species Acarinina sibaiyaensis and A. africana, which, combined with the high percentages of the nannofossil Ericsonia, indicates warm and eutrophic surface waters (e.g., Ernst et al., 2006; Guasti and Speijer, 2007; Agnini et al., 2007; Luciani et al., 2007; Fig. 8).

Detrital hematite sharply increased in concentration at the onset of Assemblage E (Giusberti et al, 2007; Dallanave et al., 2010, 2012; Fig. 3). Hematite forms in soils under warm and dry conditions, and an increase in hematite in marine sediments is considered indicative of an arid climate over the adjoining land, with increased wind strength (Larrasoaña et al., 2003; Zhang et al., 2007; Itambi et al., 2009), or humid to subhumid climates with seasonal drying (Torrent et al., 2006). It is delivered to the deep-sea environment through river runoff or as aeolian dust (e.g., Zhang et al., 2007; Itambi et al., 2009). Within the CMU, hematite shows cyclical fluctuations with a $\sim 21 \mathrm{kyr}$ periodicity, but other terrigenous components (quartz and phyllosilicates) do not co-vary in abundance after a $\sim 15 \%$ increase at the onset of the CMU (Fig. 3). To explain the different abundance patterns, we interpret hematite as wind-delivered and silicate minerals as runoff-delivered. 
The hematite $\%$ peaks may be indicative of cyclical variability in wind-delivered material, rather than the earlier prevailing consistently humid climate. The lithological anomaly of the CMU, the 5-fold increase in sedimentation rates and increase in reworked Cretaceous nannofossils (Agnini et al., 2007; Fig. 8), and the silicate mineral and hematite \% records all indicate marked fluctuations in the hydrological regime throughout this interval. High hematite \% may reflect the presence of high-pressure cells over land, during an overall dry climate phase, with increased wind strength and dust delivery to the sea (Larrasoaña et al., 2003; Zhang et al., 2007; Itambi et al., 2009). In contrast, low values of hematite \% may indicate periods of greater humidity and enhanced precipitation. Such alternation of wet and arid phases favored deeper soil erosion on the continental areas surrounding the Belluno Basin (Thiry, 2000; Schmitz and Pujalte, 2003), causing major washouts during the wet phases, which may explain the 5-fold increase in sedimentation rates and $15 \%$ increase in phyllosilicate abundance in the CMU (Fig. 3).

The hematite $\%$ cycles are in phase with cycles in $\mathrm{CaCO}_{3} \%$, radiolarian abundance, and bulk carbonate $\delta^{13} \mathrm{C}$, slightly preceding the others stratigraphically (Fig. 3). During the arid climate phase, enhanced wind strength may have generated intense surface water mixing and offshore nutrient upwelling, inducing increases in primary productivity and phytoplankton blooms. The blooms in primary productivity resulted in deposition of abundant algal biomass, leading to the occurrence of peaks of pleurostomellids, stilostomellids and Siphogenerinoides brevispinosa in Assemblage E. Productivity may have remained fairly high during the wet periods, as indicated by consistently high biogenic barium throughout the CMU (Giusberti et al., 2007; Paytan et al., 2007). During the rainy periods, upwelling rates may have been lower, with nutrients mostly supplied in river runoff. The delivery of food to the seafloor may have been more continuous, but with more important input of refractory organic matter from land.

In contrast to these proxies, which show cyclicity at precessional periods throughout the CMU, higher plant $n$-alkane average chain length (ACL) and $\delta \mathrm{D}$ vary only in its lowermost $50 \mathrm{~cm}$ (Tipple et al., 2011; Fig. 9). Possibly, the sedimentary $n$-alkanes were derived from a pool of plant material produced during subsequent wet and dry phases, so that ACL and $\delta \mathrm{D}$ may represent averaged records of leaf wax $n$ alkanes produced during different mean climate states in the upper CMU. Even so, the $\delta \mathrm{D}$ values within the CMU are on average $\sim 15 \%$ lower than above and below (Fig. 9), as reported for the Cicogna section (10 km away; Krishnan et al., 2015), possibly reflecting more humid conditions/higher precipitation during the PETM wet times (e.g., Sachse et al., 2006; Smith and Freeman, 2006), or greater productivity of plant material during the wet phases. Alternatively, it may reflect a primary change in the isotopic composition of meteoric waters (Krishnan et al., 2015).
In the following benthic foraminiferal Assemblage F (upper CMU, recovery phase), Siphogenerinoides brevispinosa and Tappanina selmensis are less abundant, whereas $B u$ limina tuxpamensis, Abyssammina spp., and Nuttallides truempyi increase in relative abundance (Figs. 6, 7). These are typical deep-sea, open-ocean taxa which thrive under more oligotrophic conditions (e.g., Thomas, 1998), and might indicate progressively less intense or shorter primary productivity blooms during the arid phases, and/or mark the return to fully oxygenated seafloor and pore water conditions. Less intense eutrophy at the transition from Assemblage $\mathrm{E}$ to $\mathrm{F}$ is further supported by calcareous plankton data, showing a decrease in the planktic foraminiferal excursion species, and among nannofossils, a decrease in $\mathrm{Er}$ icsonia (Agnini et al., 2007; Luciani et al., 2007; Fig. 8). Coinciding with the top of the CMU, there were marked changes in calcareous plankton assemblages, although benthic foraminiferal Assemblage F persisted. Among calcareous nannofossils the abundance of Zygrhablithus, Sphenolithus and Octolithus increased, whereas that of reworked taxa decreased (Fig. 8). In the planktic foraminiferal assemblage, Acarinina species declined in abundance, and the fauna became more diverse, with fluctuations modulated by lithology in the marl-limestone couplets overlying the CMU (Fig. 8).

The lithological unit above the CMU consists of an alternation of limestones and marls at precessional frequencies ( 21 kyr; Fig. 2). These limestone-marl couplets persist for up to $8 \mathrm{~m}$ above the CMU (well beyond the top of the studied interval; Giusberti et al., 2007; Luciani et al., 2007), then gradually become less clearly expressed, fading upwards. The marl-limestone couplets may reflect the persistence of wet (marl)-arid (limestone) cycles for $\sim 800 \mathrm{kyr}$ after the end of the CMU deposition, though at an amplitude declining over time. This persistence resembles the extended (650 kyr) humid period, starting at the onset of PETM, recognized in the sediment record at Site 401 of eastern North Atlantic (Bornemann et al., 2014). Our benthic foraminiferal data agree with this interpretation, showing substantially unchanged seafloor conditions up to $+650 \mathrm{~cm}$ (uppermost sample analyzed).

\subsection{Clues from Forada on PETM climate change}

The integrated data set collected at Forada supports the occurrence of enhanced climatic contrasts and productivity changes in the western Tethys during the PETM, and agrees with previous studies suggesting intense weather extremes at mid- to subtropical latitudes (Fig. 10; Table S3). At the onset of the PETM, middle to subtropical latitudes may have been characterized by intense, monsoonal-type rainfall, followed by a succession of wet and arid phases, possibly precessionally paced, during the core of the PETM (e.g., Collinson et al., 2007; Kraus and Rigging, 2007; Egger et al., 2009; Foreman et al., 2014; Stassen et al., 2012a, b; 2015; Fig. 10 and 


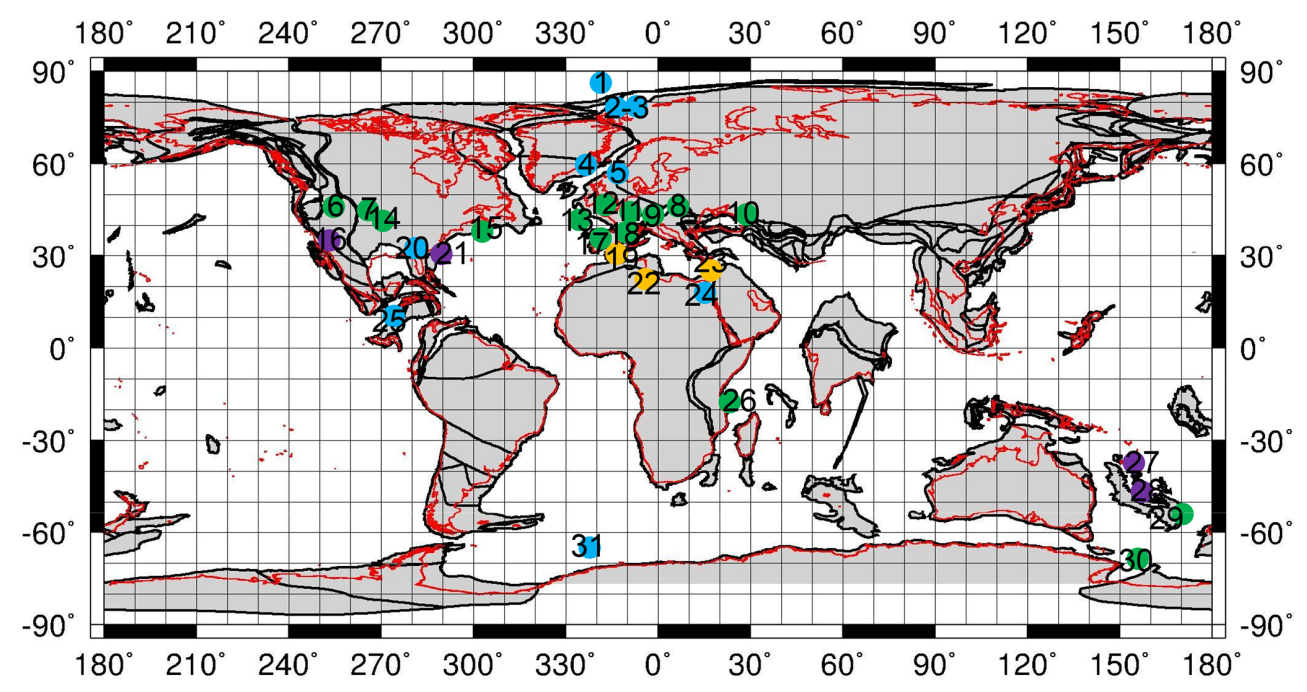

55.0 Ma Reconstruction

Figure 10. Paleogeographic map (from http://www.odsn.de/odsn/services/paleomap/paleomap.html) at 55 Ma showing sites where paleohydrological reconstructions for the PETM are available. Numbers follow a north to south paleolatitudinal order. Blue dots indicate areas where an increase in precipitation has been inferred; green dots indicate areas where an increase in climatic contrasts or a fluctuating precipitation regime has been inferred; orange dots indicate areas where an increase in aridity has been inferred; purple dots indicate areas where hydrological changes have been inferred but the pattern not specified. (1) Lomonosov Ridge, Arctic Sea; (2, 3) Spitsbergen central basin and Svalbard archipelago area; (4) central North Sea Basin; (5) eastern North Sea Basin; (6) Williston Basin, western North Dakota, (USA) (7) Bighorn Basin, Wyoming (USA); (8) Rhenodanubian Basin, Austria; (9) Belluno Basin, northeastern Italy; (10) Aktumsuk and Kaurtakapy sections, Uzbekistan and Kazakhstan; (11) Dieppe-Hampshire Basin, France; (12) London Basin; (13) DSDP Site 401 Bay of Biscay, northeastern Atlantic Ocean; (14) western Colorado (USA); (15) New Jersey Coastal Plain (USA); (16) Central Valley of California (USA); (17) Basque Basin, northern Spain; (18) Tremp Basin, northern Spain; (19) Alamedilla section, southern Spain; (20) Tornillo Basin, Texas (USA); (21) Salisbury embayment, mid-Atlantic coastal plain (USA); (22) Gafsa Basin, Tunisia; (23) Zin Valley of Negev, Israel; (24) Dababiya section, Egypt; (25) northern Neotropics (Colombia and Venezuela); (26) TDP Site 14, Tanzania; (27) Tawanui section, North Island (New Zealand); (28) Clarence River valley, South Island (New Zealand); (29) central Westland, South Island (New Zealand); (30) ODP Site 1172, East Tasman Plateau; (31) ODP Site 690 Weddell Sea, Southern Ocean. See Table S3 for references and additional information.

Table S3). The Forada record allows for distinct recognizing the temporal successions among these distinct climatic phases up to $800 \mathrm{kyr}$ after the onset of the PETM, as well as directly relating them to the progression of the CIE, its recovery and termination. The climatic conditions inferred from the Forada section and other records at similar latitudes differ from those derived from the subtropical net evaporation zone $\left(15-35^{\circ} \mathrm{N}\right)$, (e.g., from the Tremp-Graus Basin - Pyrenees), which document a generally much drier climate with a brief interval of increased storminess and intense flash flood events at the onset of the PETM (Schmitz and Pujalte, 2007). Records from subtropical to mid-latitudes also differ from records within the northern rain belt and into the Arctic Basin $\left(>50^{\circ} \mathrm{N}\right)$, which suggests that humid conditions may have been more persistent there, with increased rates of precipitation and on average moister conditions during the PETM (Pagani et al., 2006b; Sluijs et al., 2006; Harding et al., 2011; Dypvik et al., 2011; Kender et al., 2012; Wieczorek et al., 2013; Fig. 10; Table S3).

The combination of all these climatic records (Fig. 10; Table S3) suggests that the net result of increased weather ex- tremes during the core of PETM might have been to decrease rainout at subtropical to mid-latitudes, and increase moisture transport toward the high latitudes, as originally suggested by Pagani et al. (2006b). Few tropical records exist, so that precipitation changes here are less clear. Rainfall in coastal Tanzania may have decreased during the early PETM but it was combined with violent precipitation events and floodings (Handley et al., 2008; 2012; Aze et al., 2014; Table S3). In Central America, conditions during the PETM may have shifted to more continuously humid (Jaramillo et al., 2010).

The long-lasting cyclicity and precise chronology at Forada suggest that this enhanced climate variability at subtropical to mid-latitudes may have lasted for several hundred thousand years after the onset of the CIE. Despite the possible decrease in net rainout, these weather extremes persisting over several $10^{5} \mathrm{kyr}$ may have significantly enhanced the rate of erosion and weathering, through the occurrence of alternating wet-dry periods. The weathering may have led to a decrease in atmospheric $\mathrm{CO}_{2}$ levels by consumption of $\mathrm{CO}_{2}$ during weathering reactions. The increased supply of cations through enhanced weathering-erosion would have 
driven ocean $\mathrm{pH}$ up and atmospheric $\mathrm{CO}_{2}$ down (Broecker and Peng, 1982; Raymo et al., 1988; Zachos et al., 2005). Enhanced seasonal extremes across large geographical areas (the subtropical to mid-latitudinal belt) thus might have been a response to the large $\mathrm{CO}_{2}$ input at the Paleocene-Eocene transition, and may have had a primary role in restoring the carbon cycle to steady state.

\section{Conclusions}

The continuous and expanded record of benthic foraminifera across the PETM at Forada, integrated with the extensive data sets previously generated across this interval, may provide the most complete reconstruction of ecological and climatic changes during the Paleocene-Eocene Thermal Maximum in Europe. Coupled sedimentological, molecular and micropaleontological records highlight a complex sequence of environmental and climatic changes during the time period across the CIE:

- Climatic and oceanographic conditions started to change $\sim 30$ kyr before the onset of the PETM, with a possible precursor event.

- Our high-resolution benthic foraminiferal record combined with the established chronology lets us infer that the BEE in the central-western Tethys occurred over a time interval of not more than $4 \mathrm{kyr}$. At the onset of the PETM, combined de-oxygenation, acidification and environmental instability may have synergistically impacted deep-sea life.

- Four benthic foraminiferal assemblages occur $(\mathrm{C}-\mathrm{E}$ and lower F) within the CMU (coinciding with the main phase of CIE). Assemblage $\mathrm{C}$ is characterized by successive peaks of different agglutinated recolonizers. Calcareous recolonizers return in the following assemblage, after calcium carbonate saturation increased. The complex succession of peaks of agglutinated and hyaline recolonizers in these two assemblages $(C, D$; $12.5 \mathrm{kyr}$ ) suggests multiple repopulation episodes. The benthic foraminiferal data integrated with molecular and mineralogical data point to increased precipitation and strong continental erosion during this short initial stage of the PETM.

- Within the core of the CIE, $\delta^{13} \mathrm{C}$ and mineralogical properties such as hematite and calcium carbonate wt $\%$ vary at precessional periodicity. Combined with data on radiolarian abundance and benthic foraminiferal assemblage composition, this variability suggests an alternation of overall wetter and drier periods. Enhanced weather extremes during most of the PETM may have led to a decrease in total precipitation over the centralwestern Tethys.
- The benthic foraminiferal assemblage at Forada did not significantly change with the onset of the deposition of marl-limestone couplets unit above the CMU (middle and upper third of Assemblage F). This suggests that the enhanced climatic variability at precessional timescales persisted well after the end of the CIE recovery. We argue that enhanced seasonal extremes at mid-latitudes might have been a direct climate response to the huge $\mathrm{CO}_{2}$ input at the Paleocene-Eocene transition, and may have had a primary role in restoring carbon cycle steady state through links with the water cycle and weathering rates.

\section{The Supplement related to this article is available online at doi:10.5194/cp-12-213-2016-supplement.}

Acknowledgements. This work was funded by the Italian Ministry of Education and Research (MIUR) funds (PRIN 2001, 2007 and 2010-2011 to Domenico Rio; no. prot. 2001048975_002; 2007W9B2WE_004; 2010X3PP8J_003). This manuscript benefited from constructive reviews of Robert Speijer and Nicoletta Mancin. L. Giusberti and F. Boscolo Galazzo are deeply indebted to Domenico Rio for the original idea of the "Paleogene Veneto Project", the financial and material support, and for fruitful discussions during all these years. E. Thomas acknowledges financial support by the Leverhulme Foundation (UK) and NSF grant OCE 1232413.

Edited by: L. Beaufort

\section{References}

Agnini, C., Fornaciari, E., Rio, D., Tateo, F., Backman, J., and Giusberti, L.: Response to calcareous nannofossil assemblages, mineralogy and geochemistry to the environmental perturbations across the Paleocene/Eocene boundary in the Venetian Pre-Alps, Mar. Micropaleont., 63, 19-38, 2007.

Agnini, C., Macrì, P., Backman, J., Brinkhuis, H., Fornaciari, E., Giusberti, G., Luciani, V., Rio, D., Sluijs, A., and Speranza, F.: An early Eocene carbon cycle perturbation at $\sim 52.5 \mathrm{Ma}$ in the Southern Alps: chronology and biotic response, Paleoceanography, 24, PA2209, doi:10.1029/2008PA001649, 2009.

Alegret, L., Molina, E., and Thomas, E.: Benthic foraminiferal faunal turnover across the Cretaceous/Tertiary Boundary at Agost (Southeastern Spain), Mar. Micropaleont, 48, 251-279, 2003.

Alegret, L., Ortiz, S., Arenillas, I., and Molina, E.: Palaeoenvironmental turnover across the Palaeocene/Eocene boundary at the Stratotype section in Dababiya (Egypt) based on benthic foraminifera, Terra Nova, 17, 526-536, 2005.

Alegret, L., Ortiz, N., and Molina, E.: Extinction and recovery of benthic foraminifera across the Paleocene-Eocene Thermal Maximum at the Alamedilla section (Southern Spain), Palaeogeogr. Palaeocl. Palaeoecol., 279, 186-200, 2009a. 
Alegret, L., Ortiz, S., Orue-Extebarria, X., Bernaola, G., Baceta, J. I., Monechi, S., Apellaniz, E., and Pujalte, V.: The PaleoceneEocene Thermal Maximum: New data on microfossil turnover at the Zumaia section, Spain, Palaios, 24, 318-328, 2009 b.

Alegret, L., Ortiz, S., Arenillas, I., and Molina, E.: What happens when the ocean is overheated? The foraminiferal response across the Paleocene-Eocene Thermal Maximum at the Alamedilla section (Spain), Geol. Soc. Am. Bull., 122, 1616-1624, 2010.

Alve, E. and Goldstein, S. T.: Propagule transport as a key method of dispersal in benthic foraminifera (Protists), Limnol. Oceanogr., 48, 2163-2170, 2003.

Arndt, S., Jørgense, B. B., LaRowe, D. E., Middeburg, J. J., Pancost, R. D., and Regnier, P.: Quantifying the degradation of organic matter in marine sediments: a review and synthesis, Earth-Sci. Rev., 123, 53-86, 2013.

Arreguín-Rodríguez, G. J., Alegret, L., and Ortiz, S.: Glomospira acme during the Paleocene-Eocene Thermal Maximum: response to $\mathrm{CaCO}_{3}$ dissolution or to ecological forces?, J. Foramin. Res., 43, 37-49, 2013.

Arreguín-Rodríguez, G. J., Alegret, L., Sepúlveda, J., Newman, S., and Summons, R. E.: Enhanced terrestrial input supporting the Glomospira acme across the Paleocene-Eocene boundary in Southern Spain, Micropaleontology, 60, 43-51, 2014.

Aubry, M.-P., Ouda, K., Dupuis, C., Berggren, W. A., Van Couvering, J. A., Ali, J., Brinkhuis, H., Gingerich, P. R., HeilmannClausen, C., Hooker, J., Kent, D. V., King, C., Knox, R. W. O. B., Laga, P., Molina, E., Schmitz, B., Steurbaut, E., and Ward, D. R.: The Global Standard Stratotype-Section and Point (GSSP) for the base of the Eocene Series in the Dababiya section (Egypt), Episodes, 30, 271-286, 2007.

Aze, T., Pearson, P. N., Dickson, A. J., Badger, M. P. S., Bown, P. R., Pancost, R. D., Gibbs, S. J., Huber, B. T., Leng, M. J., Coe, A. L., Cohen, A. S., and Foster, G. L.: Extreme warming of tropical waters during the Paleocene-Eocene Thermal Maximum, Geology, 42, 739-742, 2014.

Bains, S., Corfield, R. M., and Norris, R. D.: Mechanisms of climate warming at the end of the Paleocene, Science, 285, 724727, 1999.

Bąk, K.: Deep-water agglutinated foraminiferal changes across the Cretaceous/Tertiary and Paleocene/Eocene transitions in the deep flysch environment; eastern part of Outer Carpathians (Bieszczady Mts, Poland), in: Proceedings of the Six International Workshop on Agglutinated Foraminifera, Prague, Czech Republic, 1-7 September 2001, edited by: Bubik, M. and Kaminski, M. A., Grzybowski Foundation Special Publication, Drukarnia Narodowa, Kraków, 8, 1-56, 2004.

Barry. J. P., Buck, K. R, Lovera, C. F., Kuhnz, L., Whaling, P. J., Peltzer, E. T., Walz, P., and Brewer, P. G.: Effects of Direct Ocean $\mathrm{CO}_{2}$ Injection on Deep-Sea Meiofauna, J. Oceanogr., 60, 759766, 2004.

Beckmann, J. P.: Distribution of benthonic foraminifera at the Cretaceous-Tertiary boundary of Trinidad (West Indies), in: International Geological Congress Report, 21 Session Norden, Copenhagen, Part 5, The Cretaceous-Tertiary Boundary, 57-59, 1960.

Benjamini, C.: The Paleocene-Eocene boundary in Israel. A candidate for the boundary stratotype, Neues Jahrb. Geol. P.-A., 186, 49-61, 1992.
Berggren, W. A. and Aubert, J.: Paleocene benthonic foraminiferal biostratigraphy, paleobiogeography and paleoecology of Atlantic-Tethyan regions: Midway type fauna, Palaeogeogr. Palaeocl. Palaeoecol., 18, 73-192, 1975.

Berggren, W. A. and Miller, K. G.: Cenozoic bathyal and abyssal calcareous benthic foraminiferal zonation, Micropaleontology, 35, 308-320, 1989.

Bernhard, J. M. and Sen Gupta, B. K.: Foraminifera of oxygen deplete environments, in: Modern Foraminifera, edited by: Sen Gupta, B. K., Dordrecht, Kluwer Academic Publihers, 201-216, 1999.

Boersma, A.: Oligocene and Other Tertiary Benthic Foraminifers from a Depth Traverse Down Walvis Ridge, Deep Sea Drilling Project Leg 74, Southeast Atlantic, Initial Rep. Deep Sea, 75, 1273-1300, 1984.

Boltovskoy, E., Scott, D. B., and Medioli, F. S.: Morphological variations of benthic foraminiferal tests in response to changes in ecological parameters; a review, J. Palaeontol., 65, 175-185, 1991.

Bornemann, A., Norris, R. D., Lyman, J. A., D'haenens, S., Groeneveld, J., Röhl, U., Farley, K. A., and Speijer, R. P.: Persistent environmental change after the Paleocene-Eocene Thermal Maximum in the eastern North Atlantic, Earth Planet. Sc. Lett., 394, 70-81, 2014.

Boscolo Galazzo, F., Giusberti, L., Luciani, V., and Thomas, E.: Paleoenvironmental changes during the Middle Eocene Climatic Optimum (MECO) and its aftermath: the benthic foraminiferal record from the Alano section (NE Italy), Palaeogeogr. Palaeocl., 378, 22-35, 2013.

Boscolo Galazzo, F., Thomas, E., Pagani, M., Warren, C., Luciani, V., and Giusberti, L.: The middle Eocene climatic optimum (MECO): A multiproxy record of paleoceanographic changes in the southeast Atlantic (ODP Site 1263, Walvis Ridge), Paleoceanography, 29, 1143-1161, 2014.

Boscolo Galazzo, F., Thomas, E., and Giusberti, L.: Benthic foraminiferal response to the Middle Eocene Climatic Optimum (MECO) in the Southeastern Atlantic (ODP Site 1263). Palaeogeogr. Palaeocl. Palaeoecol., 417, 432-444, 2015.

Bowen, G. J., Beerling, D. J., Koch, P. L., Zachos, J. C., and Quattlebaum, T.: A humid climate state during the Palaeocene/Eocene thermal maximum, Nature, 432, 495-499, 2004.

Bowen, G. J., Maibauer, B. J., Kraus, M. J., Röhl, U., Westerhold. T., Steike, A., Gingerich, P. D., Wing, S. L., and Clyde, W. J.: Two massive, rapid release of carbon during the onset of the Palaeocene-Eocene thermal maximum, Nat. Geosci., 8, 44-47, 2015.

Braga, G., De Biase, R., Gruning, A., and Proto Decima, F.: Foraminiferi bentonici del Paleocene e dell'Eocene della sezione di Possagno, in: Monografia micropaleontogica sul Paleocene e l'Eocene di Possagno, Provincia di Treviso, Italia, edited by: Bolli, H. M., Schweizerische Paläontologische Abhandlungen, Basel, 97, 85-111, 1975.

Bralower, T. J.: Evidence of surface water oligotrophy during the Paleocene-Eocene thermal maximum: Nannofossil assemblage data from Ocean Drilling Program Site 690, Maud Rise, Weddell Sea, Paleoceanography, 17, 13-1-13-12, 2002.

Broecker, W. S. and Peng, T.-H.: Tracers in the sea. Palisades, New York, Eldigio Press, 690 pp., 1982. 
Buzas, M. A., Culver, S. J., and Jorissen, F. J.: A statistical evaluation of the microhabitats of living (stained) infaunal benthic foraminifera, Mar. Micropaleont., 29, 73-76, 1993.

Cetean, C., Setoyama, E., Kaminski, M. A., Neagu, T., Bubík, M., Filipescu, S., and Tyszka, J.: Eobigenerina, n. gen., a cosmopolitan deep-water agglutinated foraminifer, and remarks on species formerly assigned to the genera Pseudobolivina and Bigenerina, in: Eight International Workshop on Agglutinated Foraminifera, Abstract Volume, edited by: Filipescu, S. and Kaminski, M. A., Grzybowski Foundation Special Publication, Presa Universitara Clujeana, Romania, 14, 6-7, 2008a.

Cetean, C., Bălci, R., Kaminski, M. A., and Filipescu, S.: Biostratigraphy of the Cenomanian-Turonian boundary in the Eastern Carpathians (Dâmboviţa Valley): preliminary observations, Stud. Univ. Babeş-Bol., Geologia, 53, 11-23, 2008b.

Cetean, C., Setoyama, E., Kaminski, M. A., Neagu, T., Bubík, M., Filipescu, S., and Tyszka, J.: Eobigenerina, a cosmopolitan deepwater agglutinated foraminifer, and remarks on late Paleozoic to Mesozoic species formerly assigned to Pseudobolivina and Bigenerina, in: Proceedings of the Eight International Workshop on Agglutinated Foraminifera, edited by: Filipescu, S. and Kaminski, M. A., Grzybowski Foundation Special Publication, Presa Universitara Clujeana, Romania, 16, 19-27, 2011.

Chun, C. O. J., Delaney, M. L., and Zachos, J. C.: Paleoredox changes across the Paleocene-Eocene thermal maximum, Walvis Ridge (ODP Sites 1262, 1263, and 1266): Evidence from $\mathrm{Mn}$ and U enrichment factors, Paleoceanography, 25, PA4202, doi:10.1029/2009PA001861, 2010.

Coccioni, R. and Galeotti, S.: Orbitally induced cycles in benthic foraminiferal morphogroups and trophic structure distribution patterns from the late Albian "Amadeus Segment" (Central Italy), J. Micropalaeont., 12, 227-239, 1993.

Coccioni, R., Bancala, G., Catanzariti, R., Fornaciari, E., Frontalini, F., Giusberti, L., Jovane, L., Luciani, V., Savian, J., and Sprovieri, M.: An integrated stratigraphic record of the Palaeocene-lower Eocene at Gubbio (Italy): new insights into the early Palaeogene hyperthermals and carbon isotope excursions, Terra Nova, 45, 380-386, 2012.

Collinson, M. E., Steart, D. C., Scott, A. C., Glasspool, I. J., and Hooker, J. J.: Episodic fire, runoff and deposition at the Palaeocene-Eocene boundary, J. Geol. Soc. London, 164, 87-97, 2007.

Corliss, B. H.: Microhabitats of Benthic Foraminifera within deepsea sediments, Nature, 314, 435-438, 1985.

Corliss, B. H. and Chen, C.: Morphotype patterns of Norwegian Sea deep-sea benthic foraminifera and ecological implications, Geology, 16, 716-719, 1988.

Cramer, B. S., Wright, J. D., Kent, D. V., and Aubry, M.-P.: Orbital climate forcing of $\delta^{13} \mathrm{C}$ excursions in the late Paleoceneearly Eocene (chrons C24n-C25n), Paleoceanography, 18, 21-121-25, 2003.

Crouch, E. M., Dickens, G. R., Brinkhuis, H., Aubry, M.-P., Hollis, C. J., Rogers, K. M., and Visscher, H.: The Apectodinium acme and terrestrial discharge during the Paleocene-Eocene thermal maximum: New palynological, geochemical and calcareous nannoplankton observations at Tawanui, New Zealand, Palaeogeogr. Palaeocl. Palaeoecol., 194, 387-403, 2003.

Dallanave, E., Tauxe, L., Muttoni, G., and Rio, D.: Silicate weathering machine at work: rock magnetic data from the late Paleocene- early Eocene Cicogna section, Italy, Geochem. Geophy. Geosy., 11, Q07008, doi:10.1029/2010GC003142, 2010.

Dallanave, E., Muttoni, G., Agnini, C., Tauxe, L., and Rio, D.: Is there a normal magnetic-polarity event during the PalaeoceneEocene thermal maximum $(\sim 55 \mathrm{Ma})$ ? Insights from the palaeomagnetic record of the Belluno Basin (Italy), Geophys. J. Int., 191, 517-529, 2012.

DeConto, R. M., Galeotti, S., Pagani, M., Tracy, D., Schaefer, K., Zhang, T., Pollard, D., and Beerling, D. J.: Past extreme warming events linked to massive carbon release from thawing permafrost, Nature, 484, 87-91, 2012.

D'haenens, S., Bornemann, A., Stassen, P., and Speijer, R.: Multiple early Eocene benthic foraminiferal assemblage and $\delta^{13} \mathrm{C}$ fluctuations at DSDP Site 401 (Bay of Biscay-NE Atlantic), Mar. Micropaleont., 88/89, 15-35, 2012.

Dickens, G. R.: Down the Rabbit Hole: toward appropriate discussion of methane release from gas hydrate systems during the Paleocene-Eocene thermal maximum and other past hyperthermal events, Clim. Past, 7, 831-846, doi:10.5194/cp-7-831-2011, 2011.

Dickens, G. R., Castillo, M. M., and Walker, J. C. G.: A blast of gas in the latest Paleocene: Simulating first-order effects of massive dissociation of oceanic methane hydrate, Geology, 25, 259-262, 1997.

Dickson, A. J., Rees-Owen, R. L., März, C., Coe, A. L., Cohen, A. S., Pancost, R. D., Taylor, K., and Shcherbinina, E.: The spread of marine anoxia on the northern Tethys margin during the Paleocene-Eocene Thermal Maximum, Paleoceanography, 29, 471-488, 2014.

Di Napoli Alliata, E., Proto Decima, F., and Pellegrini, G. B.: Studio geologico, stratigrafico e micropaleontologico dei dintorni di Belluno, Memorie della Società Geologica Italiana, 9, 1-28, 1970.

Dunkley Jones, T., Lunt, D. J., Schmidt, D. N., Ridgwell, A., Sluijs, A., Valdez, P. J., and Maslin, M. A.: Climate model and proxy data constraints on ocean warming across the Paleocene-Eocene Thermal Maximum, Earth Sci. Rev., 125, 123-145, 2013.

Dypvik, H., Riber, L., Burca, F., Rüther, D., Jargvoll, D., Nagy, J., and Jochmann, M.: The Paleocene-Eocene thermal maximum (PETM) in Svalbard - clay mineral and geochemical signals, Palaeogeogr. Palaeocl., 302, 156-169, 2011.

Egger, H., Fenner, J., Heilmann-Clausen, C., Roegl, F., Sachsenhofer, R. F., and Schmitz, B.: Paleoproductivity of the northwestern Tethyan margin (Anthering section, Austria) across the Paleocene-Eocene transition, in: Causes and Consequences of Globally Warm Climates in the Early Paleogene, edited by: Wing, S. L., Gingerich, P. D., Schmitz, B., and Thomas, E., Geol. S. Am. S., Boulder, Colorado, The Geological Society of America, 369, 133-146, 2003.

Egger, H., Homayoun, M., Huber, H., Roegl, F., and Schmitz, B.: Early Eocene climatic, volcanic, and biotic events in the northwestern Tethyan Untersberg section, Austria, Palaeogeogr. Palaeocl. Palaeoecol., 217, 243-264, 2005.

Egger, H., Heilmann-Clausen, C., and Schmitz, B.: From shelf to abyss: Record of the Paleocene/Eocene-boundary in the Eastern Alps (Austria), Geol. Acta, 7, 215-227, 2009.

Ernst, S. R., Guasti, E., Dupuis, C., and Speijer, R. P.: Environmental perturbation in the southern Tethys across the Pale- 
ocene/Eocene boundary (Dababyia, Egypt): Foraminiferal and clay minerals record, Mar. Micropaleont., 60, 89-111, 2006.

Fontanier, C., Jorissen, F. J., Chaillou, G., Anschutz, P., Gremare, A., and Griveaud, C.: Live foraminiferal faunas from a $2800 \mathrm{~m}$ deep lower canyon station from the Bay of Biscay: faunal response to focusing of refractory organic matter, Deep-Sea Res. Pt. I, 52, 1189-1227, 2005.

Fontanier, C., Jorissen, F. J., Anschutz, P., and Chaillou, G.: Seasonal variability of benthic foraminiferal faunas at $1000 \mathrm{~m}$ depth in the Bay of Biscay, J. Foramin. Res., 36, 61-76, 2006a.

Fontanier, C., Mackensen, A., Jorissen, F. J., Anschutz, P., Licari, L., and Griveaud, C.: Stable oxygen and carbon isotopes of live benthic foraminifera from the Bay of Biscay: Microhabitat impact and seasonal variability, Mar. Micropaleont., 58, 159-183, 2006b.

Fontanier, C., Duros, P., Toyofuku, T., Oguri, K., Koho, K. A., Buscail, R., Grémare, A., Radakovitch, O., Deflandre, B., de Nooijer, L.J., Bichon, S., Goubet, S., Ivanovsky, A., Chabaud, G., Menniti, C., Reichart, G.-J., and Kitazato, H.: Living (stained) deep-sea foraminifera off Hachinohe (NE JAPAN, Western Pacific): environmental interplay in oxygen-depleted ecosystems, J. Foramin. Res., 44, 281-299, 2014.

Foreman, B. Z., Heller, P. L., and Clementz, M. T.: Fluvial response to abrupt global warming at the Palaeocene/Eocene boundary, Nature, 491, 92-95, 2014.

Fornaciari, E., Giusberti, L., Luciani, V., Tateo, F., Agnini, C., Backman, J., Oddone, M., and Rio, D.: An expanded CretaceousTertiary transition in a pelagic setting of the Southern Alps (central-western Tethys), Palaeogeogr. Palaeocl., 255, 98-131, 2007.

Foster, L. C., Schmidt, D. N., Thomas, E., Arndt, S., and Ridgwell, A.: Surviving rapid climate change in the deep sea during the Paleogene hyperthermals, Proc. Natl. Acad. Sci. USA, 110, 92739276, 2013.

Frenzel, P.: Die benthischen Foraminiferen der Ruegener Schreibkreide (Unter Maastricht, NE Deutschland), Neue Palaeontologische Abhandlungen, Dresden, Germany, C Press Verlag, Band 3, 2000.

Friedrich, O.: Benthic foraminifera and their role to decipher paleoenvironment during mid-Cretaceous Oceanic Anoxic Events - "the anoxic benthic foraminifera" paradox, Revue de Micropaléontologie, 177, 2-18, 2009.

Friedrich, O., Nishi, H., Pross, J., Schmiedel, G., and Hemleben, C.: Millennial-to centennial scale interruptions of the Oceanic Anoxic Event 1b (early Albian, mid Cretaceous) inferred from benthic foraminiferal repopulation events, Palaios, 20, 64-77, 2005.

Galeotti, S., Kaminski, M. A., Coccioni, R., and Speijer, R.: High resolution deep water agglutinated foraminiferal record across the Paleocene/Eocene transition in the Contessa Road Section (central Italy), in: Proceedings of the Sixth International Workshop on Agglutinated Foraminifera, edited by: Bubik, M. and Kaminski, M. A., Grzybowski Foundation Special Publication, Drukarnia Narodowa, Kraków, 8, 83-103, 2004.

Garel, S., Schnyder, J., Jacob, J., Dupuis, C., Boussafir, M., Le Milbeau, C., Storme, J.-Y., Iakovleva, A. I., Yans, J., Baudin, F., Fléhoc C., and Quesnel, F.: Paleohydrological and paleoenvironmental changes recorded in terrestrial sediments of the
Paleocene-Eocene boundary (Normandy, France), Palaeogeogr. Palaeocl., 376, 184-199, 2013.

Gavrilov, Y. O., Kodina, L. A., Lubchenko, I. Y., and Muzylev, N. G.: The late Paleocene anoxic event in epicontinental seas of Peri-Tethys and formation of the sapropelite unit; sedimentology and geochemistry, Lithol. Miner. Resour., 32, 427-450, 1997.

Gibbs, S. J., Bralower, T. J., Bown, P. R., Zachos, J. C., and Bybell, L. M.: Shelf and open-ocean calcareous phytoplankton assemblages across the Paleocene-Eocene Thermal Maximum: Implications for global productivity gradients, Geology, 34, 233-236, 2006.

Gibson, T. G., Bybell, L. M., and Owens, J. P.: Latest Paleocene lithologic and biotic events in neritic deposits of southwestern New-Jersey, Paleoceanography, 8, 495-514, 1993.

Gibson, T. G., Bybell, L. M., and Mason, D. B.: Stratigraphic and climatic implications of clay mineral changes around the Paleocene/Eocene boundary of the northeastern US margin, Sediment. Geol., 134, 65-92, 2000.

Gingerich, P. D.: Mammalian response to climate change at the Paleocene-Eocene boundary: Polecat Bench record in the northern Bighorn Basin, Wyoming, in: Geol. S. Am. S., edited by: Wing, S. L., Gingerich, P. D., Schmitz, B., and Thomas, E., Boulder, Colorado, The Geological Society of America, 369, 463478, 2003.

Giusberti, L., Rio, D., Agnini, C., Backman, J., Fornaciari, E., Tateo, F., and Oddone, M.: Mode and tempo of the PaleoceneEocene Thermal Maximum from the Venetian pre-Alps, Geol. Soc. Am. Bull., 119, 391-412, 2007.

Giusberti, L., Coccioni, R., Sprovieri, M., and Tateo, F.: Perturbation at the sea floor during the Paleocene-Eocene Thermal Maximum: evidence from benthic foraminifera at Contessa Road, Italy, Mar. Micropaleont., 70, 102-119, 2009.

Gooday, A. J.: Deep-sea benthic foraminiferal species which exploit phytodetritus: characteristic features and controls on distribution, Mar. Micropal., 22, 187-205, 1993.

Gooday, A. J.: The biology of deep-sea Foraminifera: a review of some advances and their applications in paleoceanography, Palaios, 9, 14-31, 1994.

Gooday, A. J.: Benthic foraminifera (Protista) as tools in deep-water paleoceanography: Environmental influences on faunal characteristics, Adv. Mar. Biol., 46, 1-90, 2003.

Gooday, A. J., Hughes, J. A., and Levin, L. A.: The foraminiferan macrofauna from three North Carolina (USA) slope sites with contrasting carbon flux: a comparison with the metazoan macrofauna, Deep-Sea Res. Pt. I, 48, 1709-1739, 2001.

Gooday, A. J., Nomaki, H., and Kitazato, H.: Modern deep-sea benthic foraminifera: a brief review of their morphology-based biodiversity and trophic diversity, in: Biogeochemical Controls on Palaeoceanographic Environmental Proxies, edited by: Austin, W. E. N. and James, R. H., Geol. Soc. Spec. Publ., Bath, UK, The Geological Society Publishing House, 303, 97-119, 2008.

Guasti, E. and Speijer, R. P.: The Paleocene-Eocene Thermal Maximum in Egypt and Jordan: An overview of the planktic foraminiferal record, in: Large Ecosystem Perturbations: Causes and Consequences, edited by: Monechi, S., Coccioni, R., and Rampino, M., Geol. S. Am. S., Boulder, Colorado, The Geological Society of America, 424, 53-67, 2007.

Gupta, A. K. and Thomas, E.: Latest Miocene-Pleistocene productivity and deep-sea ventilation in the northwestern Indian Ocean 
(Deep Sea Drilling Project Site 219), Paleoceanography, 14, 6273, 1999.

Gupta, A. K. and Thomas, E.: Initiation of Northern Hemisphere glaciation and strengthening of the northeast Indian monsoon: Ocean Drilling Program Site 758, eastern equatorial Indian Ocean, Geology, 31, 47-50, 2003.

Gupta, A. K., Sundar Raj, M., Mohan, K., and De, S.: A major change in monsoon-driven productivity in the tropical Indian Ocean during ca 1.2-0.9 Myr: Foraminiferal faunal and stable isotope data, Palaeogeogr. Palaeocl., 261, 234-245, 2008.

Hammer, Ø., Harper, D. A. T., and Ryan, P. D.: PAST: Paleontological Statistics Software Package for Education and Data Analysis, Palaeontol. Electron., 4, 1-9, 2001.

Hancock, H. J. L. and Dickens, G. R.: Carbonate dissolution episodes in Paleocene and Eocene sediment, Shatsky Rise, westcentral Pacific, in: Proceedings of the Ocean Drilling Program, edited by: Bralower, T. J., Premoli Silva, I., and Malone, M. J., Scientific Results, 198, http://www-odp.tamu.edu/publications/ 198_SR/116/116.htm, 2005.

Handley, L., Pearson, P. N., McMillan, I. K., and Pancost, R. D.: Large terrestrial and marine carbon and hydrogen isotope excursions in a new Paleocene/Eocene boundary section from Tanzania, Earth Planet. Sc. Lett., 275, 17-25, 2008.

Handley, L., O'Halloran, A., Pearson, P. N., Hawkins, E., Nicholas, C. J., Schouten, S., McMillan, I. K., and Pancost, R. D.: Changes in the hydrological cycle in tropical East Africa during the Paleocene-Eocene Thermal Maximum, Palaeogeogr. Palaeocl., 329/330, 10-21, 2012.

Harding, I. C., Charles, A. J., Marshall, J. E. A., Pälike, H., Roberts, A. P., Wilson, P. A., Jarvis, E., Thorne, R., Morris, E., Moremon, R., Pearce, R. B., and Akbari, S.: Sea-level and salinity fluctuations during the Paleocene-Eocene thermal maximum in Arctic Spitsbergen, Earth Planet. Sc. Lett., 303, 97-107, 2011.

Harries, P. J. and Kauffman, E. G.: Patterns of survival and recovery following the Cenomanian-Turonian (Late Cretaceous) mass extinction in the Western Interior Basin, United States, in: Extinction events in Earth History, edited by: Kauffman, E. G. and Walliser, O. H., Lect. Notes Earth Sci. Heidelberg Germany, Springer-Verlag, 30, 277-298, 1990.

Hayward, B. W., Johnson, K., Sabaa, A. T., Kawagata, S., and Thomas, E.: Cenozoic record of elongate, cylindrical, deep-sea benthic foraminifera in the North Atlantic and equatorial Pacific Oceans, Mar. Micropaleont., 62, 141-162, 2010a.

Hayward, B. W., Sabaa, A. T., Thomas, E., Kawagata, S., Nomura, R., Schroder Adams, C., Gupta, A. K., and Johnson, K.: Cenozoic record of elongate, cylindrical, deep-sea benthic foraminifera in the Indian Ocean (ODP Sites 722, 738, 744, 758, and 763), J. Foramin. Res., 40, 113-133, 2010 b.

Hayward, B. W., Kawagata, S., Sabaa, A. T., Grenfell, H. R., van Kerckhoven, L., Johnson, K., and Thomas, E.: The Last Global Extinction (Mid-Pleistocene) of DeepSea Benthic Foraminifera (Chrysalogoniidae, Ellipsoidinidae, Glandulonodosariidae, Plectofrondiculariidae, Pleurostomellidae, Stilostomellidae), their Late Cretaceous-Cenozoic History and Taxonomy, Cushman Foundation for Foraminiferal Research Special Publication, 43, Allen Press, Lawrence, USA, 408 pp., 2012.

Higgs, N. C., Thomson, J., Wilson T. R. S., and Croudace, I. W.: Modification and complete removal of eastern Mediterranean sapropels by postdepositional oxidation, Geology, 22, 423-426, 1994.

Holbourn, A. and Kuhnt, W.: No extinctions during Oceanic Anoxic Event lb: the Aptian-Albian benthic foraminiferal record of ODP Leg 171, edited by: Kroon, D., Norris, R. D., and Klaus, A., Geol. Soc. London, Spec. Publ., Bath, UK, The Geological Society Publishing House, 183, 73-92, 2001.

Holbourn, A., Kuhnt, W., and Erbacher, J.: Benthic foraminifers from lower Albian black shales (Site 1049, ODP Leg 171): evidence for a non "uniformitarian" record, J. Foramin. Res., 31, 60-74, 2001.

Hönisch, B., Ridgwell, A., Schmidt, D. N., Thomas, E., Gibbs, S. J., Sluijs, A., Zeebe, R., Kump, L., Martindale, R. C., Greene, S. E., Kiessling, W., Ries, J., Zachos, J. C., Royer, D. L., Barker, S., Marchitto, T. M., Moyer, R., Pelejero, C., Ziveri, P., Foster, G. L., and Williams, B.: The Geological Record of Ocean Acidification, Science, 335, 1058-1963, 2012.

Ishman, S. E. and Domack, E. W.: Oceanographic controls on benthic foraminifers from the Bellingshausen margin of the Antarctic Peninsula, Mar. Micropaleont., 24, 119-155, 1994.

Itambi, A. C., von Dobeneck, T., Mulitza, S., Bickert, T., and Heslop, D.: Millennial-scale northwest African droughts related to Heinrich events and Dansgaard-Oeschger cycles: Evidence in marine sediments from offshore Senegal, Paleoceanography, 24, PA1205, doi:10.1029/2007PA001570, 2009.

Jaramillo, C. A., Ochoa, D., Contreras, L., Pagani, M., CarvajalOrtiz, H., Pratt, L. M., Krishnan, S., Cardona, A., Romero, M., Quiroz, L., Rodriguez, G., Rueda, M. J., De la Parra, F., Morón, S., Green, W., Bayona, G., Montes, C., Quintero, O., Ramirez, R., Mora, G., Schouten, S., Bermudez, H., Navarrete, R., Parra, F., Alvarán, M., Osorno, J., Crowley, J. L., Valencia, V., and Vervoort, J.: Effects of rapid global warming at the PaleoceneEocene boundary on Neotropical vegetation, Science, 330, 957961, 2010.

John, C. M., Bohaty, S. M., Zachos, J. C., Sluijs, A., Gibbs, S., Brinkhuis, H., and Bralower, T. J.: North American continental margin records of the Paleocene-Eocene thermal maximum: Implications for global carbon and hydrological cycling, Paleoceanography, 23, PA2217, doi:10.1029/2007PA001465, 2008.

John, E. H., Pearson, P. N., Coxall, H. K., Birch, H., Wade, B. S., and Foster, G. L.: Warm ocean processes and carbon cycling in the Eocene, Phil. T. Roy. Soc. A, 371, 20130099 , doi:10.1098/rsta.2013.0099, 2013.

John, E. H., Wilson, J. D., Pearson, P. N., and Ridgwell, A.: Temperature-dependent remineralization and carbon cycling in the warm Eocene oceans, Palaeogeogr. Palaeocl., 413, 158-166, 2014.

Jones, R. W. and Charnock, M. A.: "Morphogroups" of agglutinated foraminifera. Their life positions and feeding habits and potential applicability in (paleo)ecological studies, Revue de Paléobiologie, 4, 311-320, 1985.

Jorissen, F. J.: Benthic foraminiferal successions across late Quaternary Mediterranean sapropels, Mar. Geol., 153, 91-101, 1999.

Jorissen, F. J., De Stigter, H. C., and Widmark, J. G. V.: A conceptual model explaining benthic foraminiferal microhabitats, Mar. Micropaleont., 26, 3-15, 1995.

Jorissen, F. J., Fontanier, C., and Thomas, E.: Paleoceanographical proxies based on deep-sea benthic foraminiferal assemblage characteristics, in: Proxies in Late Cenozoic Paleoceanography: 
Pt. 2: Biological tracers and biomarkers, edited by: HillaireMarcel, C. and A. de Vernal, A., 1, Elsevier, Amsterdam, The Netherlands, 264-325, 2007.

Kaiho, K.: Phylogeny of deep-sea calcareous trochospiral benthic foraminifera: evolution and diversification, Micropalentology, 44, 291-311, 1998.

Kaiho, K., Arinobu, T., Ishiwatari, R., Morgans, H. E. G., Okada, H., Takeda, N., Tazaki, K., Zhou, G. P., Kajiwara, Y., Matsumoto, R., Hirai, A., Niitsuma, N., and Wada, H.: Latest Paleocene benthic foraminiferal extinction and environmental changes at Tawanui, New Zealand, Paleoceanography, 11, 447-465, 1996.

Kaminski, M. A. and Gradstein, F. M.: An Atlas of Paleogene Cosmopolitan Deep-Water Agglutinated Foraminifera, Grzybowski Foundation Special Publication, Drukarnia Narodowa, Kraków, 10, 547 pp., 2005.

Kaminski, M. A., Kuhnt, W., and Radley, J. D.: Paleocene-Eocene deep water agglutinated foraminifera from the Numidian Flysch (Rift, Northern Morocco): Their significance for the paleoceanography of the Gibraltar gateway, J. Micropaleontol., 15, 1-19, 1996.

Katz, M. E., Wright, J. D., Katz, D. R., Miller, K. G., Pak, D. K., Shackleton, N. J., and Thomas, E.: Early Cenozoic benthic foraminiferal isotopes: species reliability and interspecies correction factors, Paleoceanography, 18, 1024, doi:10.1029/2002PA000798, 2003.

Kelly, D. C., Bralower, T. J., Zachos, J. C., Premoli Silva, I., and Thomas, E.: Rapid diversification of planktonic foraminifera in the tropical Pacific (ODP Site 865) during the late Paleocene thermal maximum, Geology, 24, 423-426, 1996.

Kelly, D. C., Bralower, T. J., and Zachos, J. C.: Evolutionary consequences of the latest Paleocene thermal maximum for tropical planktonic foraminifera, Palaeogeogr., 141, 139-161, 1998.

Kelly, D. C., Nielsen, T. M. J., McCarren, H. K., Zachos, J. C., and Röhl, U.: Spatiotemporal patterns of carbonate sedimentation in the South Atlantic: Implications for carbon cycling during the Paleocene-Eocene thermal maximum, Palaeogeogr. Palaeocl. Palaeoecol., 293, 30-40, 2010.

Kender, S., Stephenson, M. H., Riding, J.,B., Leng, M. J., O’BKnox, R. W., Peck, V. L., Kendrick, C. P., Ellis, M. A., Vane, C. H., and Jamieson, R.: Marine and terrestrial environmental changes in NW Europe preceding carbon release at the Paleocene-Eocene transition, Earth Planet. Sc. Lett., 353/354, 108-120, 2012.

Kennett, J. P. and Stott, L. D.: Abrupt deep-sea warming, palaeoceanographic changes and benthic extinctions at the end of the Palaeocene, Nature, 353, 225-229, 1991.

Kirtland Turner, S. and Ridgwell, A.: Recovering the true size of an Eocene hyperthermal from the marine sedimentary record, Paleoceanography, 28, 700-712, 2013.

Koutsoukos, E. A. M., Leary, P. M., and Hart, M. B.: Latest Cenomanian-earliest Turonian low-oxygen tolerant benthonic foraminifera: a case study from the Sergipe Basin (N.E. Brazil) and the western Anglo-Paris Basin (southern England), Palaeogeogr. Palaeocl., 77, 145-177, 1990.

Kraus, M. J. and Riggins, S.: Transient drying during the Paleocene-Eocene Thermal Maximum (PETM): analysis of paleosols in the Bighorn Basin, Wyoming, Palaeogeogr. Palaeocl., 245, 444-461, 2007.

Kraus, M. J., McInerney, F. A., Wing, S. L., Secord, R., Baczynski, A. A., and Bloch, J. I.: Paleohydrologic response to continen- tal warming during the Paleocene-Eocene Thermal Maximum, Bighorn Basin, Wyoming, Palaeogeogr. Palaeocl. Palaeoecol., 370, 196-208, 2013.

Krishnan, S., Pagani, M., and Agnini, C.: Leaf waxes as recorders of paleoclimatic changes during the Paleocene-Eocene Thermal Maximum: Regional expressions from the Belluno Basin, Org. Geochem., 80, 8-17, 2015.

Kuhnt, W.: Abyssal recolonization by benthic foraminifera after the Cenomanian/Turonian boundary anoxic event in the North Atlantic, Mar. Micropaleont., 19, 257-274, 1992.

Kuhnt, W.: Early Danian benthic foraminiferal community structures, Geulhmmerberg, SE Netherlands, Geol. Mijnbouw, 75, 163-172, 1996.

Kuhnt, W. and Collins, E. S.: Cretaceous to Paleogene benthic foraminifers from the Iberia abyssal plain, in: Proceedings of the ODP, edited by: Whitmarsh, R. B., Sawyer, D. S., Klaus, A., and Masson, D. G., Scientific Results, 149, College Station, TX Ocean Drilling Program, 203-316, 1996.

Kuhnt, W. and Kaminski, M. A.: Changes in the community structure of deep-water agglutinated foraminifers across the $\mathrm{K} / \mathrm{T}$ boundary in the Basque Basin (northern Spain), Revista Española de Micropaleontologia, 25, 57-92, 1993.

Kuhnt, W. and Kaminski, M. A.: The reponse of benthic foraminifera to the K/T boundary event-a review, in: Géologie de l'Afrique et de l'Atlantique Sud-Comptes Rendu des Colloques de géologie d'Angers, 16-20 Juillet, 1994, edited by: Jardiné, S., de Klasz, I., and Debenay, J. P., B. Cent. Rech. Expl., Memoire, Pau, Société nationale Elf Aquitaine, 16, 433-442, 1996.

Kuhnt, W., Collins, E., and Scott, D. B.: Deep water agglutinated foraminiferal assemblages across the Gulf Stream: distribution pattern and taphonomy, in: Proceedings of the Fifth International Workshop on Agglutinated Foraminifera, edited by: Hart, M. B., Kaminski, M. A., and Smart, C. W., Grzybowski Foundation Special Publication, Drukarnia Narodowa, Kraków, 7, 261-298, 2000.

Larrasoaña, J. C., Roberts, A. P., Rohling, E. J., Winklhofer, M., and Wehausen, R.: Three million years of monsoon variability over the northern Sahara, Clim. Dynam., 21, 689-698, 2003.

Levin, L. A.: Oxygen Minimum Zone Benthos: Adaptation and Community Response to Hypoxia, Oceanogr. Mar. Biol., 41, 145, 2003.

Lirer, F.: A new technique for retrieving calcareous microfossils from lithified lime deposits, Micropaleontology, 46, 365-369, 2000.

Littler, K., Röhl, U., Westerhold, T., and Zachos, J. C.: A highresolution benthic stable-isotope record for the South Atlantic: Implications for orbital-scale changes in Late Paleocene-Early Eocene climate and carbon cycling. Palaeogeogr. Palaeocl., 401, 18-30, 2014.

Luciani, V., Giusberti, L., Agnini, C., Backman, J., Fornaciari, E., and Rio, D.: The Paleocene-Eocene Thermal Maximum as recorded by Tethyan planktonic foraminifera in the Forada section (northern Italy), Mar. Micropaleont., 64, 189-214, 2007.

Ma, Z., Gray, E., Thomas, E., Murphy, B., Zachos, J. C., and Paytan, A.: Carbon sequestration during the Paleocene-Eocene Thermal maximum by an efficient biological pump, Nat. Geosci., 7, 382 388, 2014.

Mancin, N., Hayward, B. W., Trattenero, I., Cobianchi, M., and Lupi, C.: Can the morphology of deep-sea benthic foraminifera 
reveal what caused their extinction during the mid-Pleistocene Climate Transition?, Mar. Micropaleont., 104, 53-70, 2013.

McCarren, H., Thomas, E., Hasegawa, T., Röhl, U., and Zachos, J. C.: Depth dependency of the Paleocene-Eocene carbon isotope excursion: Paired benthic and terrestrial biomarker records (ODP Leg 208, Walvis Ridge), Geochem. Geophy. Geosy., 9, Q10008, doi:10.1029/2008GC002116, 2008.

McInerney, F. A. and Wing, S. L.: The Paleocene-Eocene thermal maximum: A perturbation of carbon cycle, climate, and biosphere with implications for the future, Annu. Rev. Earth Pl. Sc., 39, 489-516, 2011.

Meissner, K. J., Bralower, T. J., Alexander, K., Dunkley Jones, T., Sijp. W., and Ward, M.: The Paleocene-Eocene Thermal Maximum: how much carbon is enough?, Paleoceanography, 29, 946963, 2014

Mohan, K., Gupta, A. K., and Bhaumik, A. K.: Distribution of deepsea benthic foraminifera in the Neogene of Blake Ridge, NW Atlantic Ocean, J. Micropalaeontol., 30, 33-74, 2011.

Murphy, B. H., Farley, K. A., and Zachos, J. C.: An extraterrestrial 3He-based timescale for the Paleocene-Eocene thermal maximum (PETM) from Walvis Ridge, IODP Site 1266, Geochim. Cosmochim. Ac., 74, 5098-5108, 2010.

Murray, J. W.: Ecology and palaeoecology of benthic foraminifera. Longman, Harlow, 397 pp., 1991.

Murray, J. W.: Ecology and Applications of Benthic Foraminifera, Cambridge University Press, USA, 426 pp., 2006.

Murray, J. W. and Pudsey, C. J.: Living (stained) and dead foraminifera from the newly ice-free Larsen Ice Shelf, Weddell Sea, Antarctica: ecology and taphonomy, Mar. Micropalent., 53, 67-81, 2004.

Nagy, J., Jargvoll, D., Dypvik, H., Jochmann, M., and Riber, L.: Environmental changes during the Paleocene-Eocene Thermal Maximum in Spitsbergen as reflected by benthic foraminifera, Polar Res., 32, 19737, doi:10.3402/polar.v32i0.19737, 2013.

Nicolo, M. J., Dickens, G. R., and Hollis, C. J.: South Pacific intermediate water oxygen depletion at the onset of the Paleocene-Eocene thermal maximum as depicted in New Zealand margin sections, Paleoceanography 25, PA4210, doi:10.1029/2009PA001904, 2010.

Nomura, R.: Paleogene to Neogene deep-sea paleoceanography in the eastern Indian Ocean: benthic foraminifera from ODP Sites 747, 757 and 758, Micropaleontology, 41, 251-290, 1995.

Ortiz, N.: Differential patterns of benthic foraminiferal extinctions near the Paleogene/Eocene boundary in the North Atlantic and western Tethys, Mar. Micropaleont., 26, 341-359, 1995.

Pagani, M., Caldeira, K., Archer, D., and Zachos, J. C.: An ancient carbon mystery, Science, 314, 1556-1557, 2006 a.

Pagani, M., Pedentchouk, N., Huber, M., Sluijs, A., Schouten, S., Brinkhuis, H., Sinninghe Damsté, J. S., Dickens, G. R., and the Expedition 302 Scientists: Arctic hydrology during global warming at the Palaeocene/Eocene Thermal Maximum, Nature, 442, 671-675, 2006b.

Pälike, C., Delaney, M. L., and Zachos, J. C.: Deep-sea redox across the Paleocene-Eocene thermal maximum, Geochem. Geophys. Geosy., 15, 1038-1053, 2014.

Panchuk, K., Ridgwell, A., and Kump, L. R.: Sedimentary response to Paleocene-Eocene Thermal Maximum carbon release: A model-data comparison, Geology, 36, 315-318, 2008.
Panieri, G. and Sen Gupta, B. K.: Benthic foraminifera of the Blake Ridge hydrate mound, Western North Atlantic Ocean, Mar. Micropaleont., 66, 91-102, 2007.

Paytan, A. and Griffith, E. M.: Marine barite: Recorder of variations in ocean export productivity, Deep-Sea Res. Pt. II, 54, 687-705, 2007.

Paytan, A., Averyt, K., Faul, K., Gray, E., and Thomas, E.: Barite accumulation, ocean productivity, and $\mathrm{Sr} / \mathrm{Ba}$ in barite across the Paleocene-Eocene Thermal Maximum, Geology, 35, 1139-1142, 2007.

Penman, D. E., Hönisch, B., Zeebe, R. E, Thomas, E., and Zachos, J. C.: Rapid and sustained surface ocean acidification during the Paleocene-Eocene Thermal Maximum, Paleoceanography, 29, 357-369, 2014.

Pflum, C. E. and Frerichs, W. E.: Gulf of Mexico Deep-Water Foraminifers, Cushman Foundation for Foraminiferal Research, Special Publication, 14, 125 pp., 1976.

Pierrehumbert, R. T.: The hydrologic cycle in deep-time climate problems, Nature, 419, 191-198, 2002.

Post, J. E., Thomas, E., and Heaney, P. J.: Jianshuiite in oceanic manganese nodules at the Paleocene-Eocene Boundary, Am. Mineral., 101, 407-414, doi:10.2138/am-2016-5347, 2016.

Raymo, M. E., Ruddiman, F., and Froelich, P. N.: Influence of late Cenozoic mountain building on ocean geochemical cycles, Geology, 16, 649-653, 1988.

Ravizza, G. E., Norris, R. N., Blusztajn, J., and Aubry, M.-P.: An osmium isotope excursion associated with the Late Paleocene Thermal Maximum: evidence of intensified chemical weathering, Paleoceanography, 16, 155-163, 2001.

Robert, C. and Chamley, H.: Development of early Eocene warm climates, as inferred from clay mineral variations in oceanic sediments, Global Planet. Change, 89, 315-331, 1991.

Robert, C. and Kennett, J. P.: Antarctic subtropical humid episode at the Paleocene-Eocene boundary: clay-mineral evidence, $\mathrm{Ge}-$ ology, 22, 211-214, 1994.

Rodríguez-Tovar, F. J., Uchman, A., Alegret, L., and Molina, E.: Impact of the Paleocene-Eocene Thermal Maximum on the macrobenthic community: Ichnological record from the Zumaia section, northern Spain, Mar. Geol., 282, 178-187, 2011.

Röhl, U., Westerhold, T., Bralower, T. J., and Zachos, J. C.: On the duration of the Paleocene-Eocene Thermal Maximum (PETM), Geochem. Geophy. Geosy, 8, Q12002, doi:10.1029/2007GC001784, 2007.

Sachse, D., Radke, J., and Gleixner, G.: $\delta$ D values of individual n-alkanes from terrestrial plants along a climatic gradient-implications for the sedimentary biomarker record, Org. Geochem., 37, 469-483, 2006.

Schmiedl, G.: Late Quaternary benthic foraminiferal assemblages from the eastern South Atlantic: Reconstruction of deep-water circulation and productivity changes, Reports on Polar Research, 160, 207 pp., 1995 (in German).

Schmiedl, G. and Mackensen, A.: Late Quaternary paleoproductivity and deep water circulation in the eastern South Atlantic Ocean: evidence from benthic foraminifera, Palaeogeogr. Palaeocl. Palaeoecol., 130, 43-80, 1997.

Schmiedl, G., De Bovee, F., Buscail, R., Charriere, B., Hemleben, C., Medernach, L., and Picon, P.: Trophic control of benthic foraminiferal abundance and microhabitat in the bathyal Gulf of 
Lions, western Mediterranean Sea, Mar. Micropaleont., 40, 167$188,2000$.

Schmitz, B. and Pujalte, V.: Sea-level, humidity, and land-erosion records across the initial Eocene Thermal Maximum from a continental-marine transect in northern Spain, Geology, 31, 689692, 2003.

Schmitz, B. and Pujalte, V.: Abrupt increase in seasonal extreme precipitation at the Paleocene-Eocene boundary, Geology, 35, 215-218, 2007.

Schmitz, B., Asaro, F., Molina, E., Monechi, S., Von Salis, K., and Speijer, R.: High resolution iridium, $\delta^{13} \mathrm{C}, \delta^{18} \mathrm{O}$, foraminifera and nannofossil profiles across the latest Paleocene benthic extinction event at Zumaya, Palaeogeogr. Palaeocl., 133, 49-68, 1997.

Schmitz, B., Pujalte, V., and Nùñez-Betelu, K.: Climate and sea level perturbations during the initial Eocene thermal maximum: Evidence from siliciclastic units in the Basque Basin (Ermua, Zumaia and Trabakua Pass), northern Spain, Palaeogeogr. Palaeocl., 165, 299-320, 2001.

Secord, R., Gingerich, P. D., Lohmann, K. C., and MacLeod, K. G.: Continental warming preceding the Palaeocene-Eocene thermal maximum, Nature, 467, 955-958, 2010.

Seibel, B. A. and Walsh, P. J.: Potential impacts of $\mathrm{CO}_{2}$ injection on deep-sea biota, Science, 294, 319-320, 2001.

Sgarrella, F., Sprovieri, F., Di Stefano, E., and Caruso, S.: Paleoceanography conditions at the base of the Pliocene in the Southern Mediterranean Basin, Riv. Ital. Paleontol. S., 103, 207-220, 1997.

Sing, R. K. and Gupta, A. K.: Late Oligocene-Miocene paleoceanographic evolution of the southeastern Indian Ocean: evidence from deep-sea benthic foraminifera (ODP Site 757), Mar. Micropaleont., 51, 153-170, 2004.

Sluijs, A., Schouten, S., Pagani, M., Woltering, M., Brinkhuis, H., Sinninghe Damsté, J. S., Dickens, G. R., Huber, M., Reichart, G.-J., Stein, R., Matthiessen, J., Lourens, L. J., Pedentchouk, N., Backman, J., Moran, K., and The Expedition 302 Scientists: Subtropical Arctic Ocean temperatures during the Palaeocene/Eocene Thermal Maximum, Nature, 441, 610-613, 2006.

Sluijs, A., Bowen, G. J., Brinkhuis, H., Lourens, L. J., and Thomas, E.: The Paleocene-Eocene thermal maximum super greenhouse: Biotic and geochemical signatures, age models and mechanisms of global change, in: Deep-Time Perspectives on Climate Change: Marrying the Signal From Computer Models and Biological Proxies, edited by: Williams, M., Haywood, A. M., Gregory, F. J., and Schmidt, D. N., The Micropalaeontological Society Special Publication, The Geological Society, London, 323350, 2007a.

Sluijs, A., Brinkhuis, H., Schouten, S., Bohaty, S. M., John, C. M., Zachos, J. C., Reichart, G.-J., Sinninghe Damsté, J. S., Crouch, E. M., and Dickens, G. R.: Environmental precursors to rapid light carbon injection at the Palaeocene/Eocene boundary, Nature, 450, 1218-1221, 2007b.

Sluijs, A., Bijl, P. K., Schouten, S., Röhl, U., Reichart, G.-J., and Brinkhuis, H.: Southern ocean warming, sea level and hydrological change during the Paleocene-Eocene thermal maximum, Clim. Past, 7, 47-61, doi:10.5194/cp-7-47-2011, 2011.
Smith, F. A. and Freeman, K. H.: Influence of physiology and climate on $\delta \mathrm{D}$ of leaf wax n-alkanes from $\mathrm{C} 3$ and $\mathrm{C} 4$ grasses, Geochim. Cosmochim. Ac., 70, 1172-1187, 2006.

Smith, F. A., Wing, S. L., and Freeman, K. H.: Magnitude of the carbon isotope excursion at the Paleocene-Eocene Thermal Maximum: the role of plant community change, Earth Planet. Sc. Lett., 262, 50-65, 2007.

Speijer, R. P. and Schmitz, B.: A benthic foraminiferal record of Paleocene sea level and trophic/redox conditions at Gebel Aweina, Egypt, Palaeogeogr. Palaeocl., 137, 79-101, 1998.

Speijer, R. P., Schmitz, B., Aubry, M.-P., and Charisi, S. D.: The latest Paleocene benthic extinction event: punctuated turnover in outer neritic foraminiferal faunas from Gebel Aweina, Egypt, in: Paleocene/Eocene boundary events in space and time, edited by: Aubry, M.-P. and Benjamini, C., Israel J. Earth Sci., 44, 207-222, 1996.

Speijer, R. P., Schmitz, B., and van der Zwaan, G. J.: Benthic foraminiferal extinction and repopulation in response to latest Paleocene Tethyan anoxia, Geology, 25, 683-686, 1997.

Speijer, R. P., Scheibner, C., Stassen, P., and Morsi, A.-M.: Response of marine ecosystems to deep-time global warming: a synthesis of biotic patterns across the Paleocene-Eocene thermal maximum (PETM), Austr. J. Earth Sci., 105, 6-16, 2012.

Stassen, P., Thomas, E., and Speijer, R. P.: The progression of environmental changes during the onset of the Paleocene-Eocene Thermal Maximum (New Jersey Coastal Plain), Austr. J. Earth Sci., 105, 169-178, 2012a.

Stassen, P., Thomas, E., and Speijer, R. P.: Integrated stratigraphy of the Paleocene-Eocene thermal maximum in the New Jersey Coastal Plain: Toward understanding the effects of global warming in a shelf environment, Paleoceanography, 27, PA4210, doi:10.1029/2012PA002323, 2012b.

Stassen, P., Thomas, E., and Speijer, R. P.: Paleocene-Eocene Thermal Maximum environmental change in the New Jersey Coastal Plain: benthic foraminiferal biotic events, Mar. Micropaleont., 115, 1-23, 2015.

Steineck, P. and Thomas, E.: The latest Paleocene crisis in the deep sea: ostracode succession at Maud Rise, Southern Ocean, Geology, 24, 583-586, 1996.

Stoll, H. M., Shimizu, N., Archer, D., and Ziveri, P.: Coccolithophore productivity response to greenhouse event of the Paleocene-Eocene Thermal Maximum, Earth Planet. Sc. Lett., 258, 192-206, 2007.

Suhr, S. B., Pond, D. W., Gooday, A. J., and Smith, C. R.: Selective feeding by foraminifera on phytodetritus on the western Antarctic Peninsula shelf: evidence from fatty acid biomarker analysis, Mar. Ecol.-Prog. Ser., 262, 153-162, 2003.

Takata, H., Nomura, R., and Khim, B.-K.: Response to abyssal benthic foraminifera to mid-Oligocene glacial events in the eastern Equatorial Pacific Ocean (ODP Leg 199), Palaeogeogr. Palaeocl. Palaeoecol., 292, 1-11, 2010.

Takeda, K. and Kaiho, K.: Faunal turnovers in central Pacific benthic foraminifera during the Paleocene-Eocene thermal maximum, Palaeogeogr. Palaeocl., 251, 175-197, 2007.

Thiry, M.: Palaeoclimatic interpretation of clay minerals in marine deposits: An outlook from the continental origin, Earth-Sci. Rev., 49, 201-221, 2000.

Thomas, D. J., Bralower, T. J., and Zachos, J. C.: New evidence for subtropical warming during the late Paleocene thermal max- 
imum: Stable isotopes from Deep Sea Drilling Project Site 527: Walvis Ridge, Paleoceanography, 14, 561-570, 1999.

Thomas, D. J., Zachos, J. C., Bralower, T. J., Thomas, E., and Bohaty, S.: Warming the fuel for the fire: Evidence for the thermal dissociation of methane hydrate during the Paleocene-Eocene thermal maximum, Geology, 30, 1067-1070, 2002.

Thomas, E.: Late Eocene to Recent deep-sea benthic foraminifers from the central equatorial Pacific Ocean, in: Initial Rep. Deep Sea, edited by: Mayer, L., Theyer, F., Barron, J. A., Dunn, D. A., Handyside, T., Hills, S., Jarvis, I., Nigrini, C. A., Pisias, N. C., Pujos, A., Saito, T., Stout, P., Thomas, E., Weinreich, N., and Wilkens, R. H., US Government Printing Office, Washington, 655-656, 1985.

Thomas, E.: Development of Cenozoic deep-sea benthic foraminiferal faunas in Antarctic waters, Geol. Soc. Spec. Publ, 47, 283-296, 1989.

Thomas, E.: Late Cretaceous through Neogene deep-sea benthic foraminifers (Maud Rise, Weddell Sea, Antarctica), in: Proceedings of the Ocean Drilling Program, Scientific Results, edited by: Barker, P. F., Kennett, J. P., O'Connell, S., Berkowitz, S., Bryant, W. R., Burckle, L. H., Egeberg, P. K., Fiitterer, D. K., Qersonde, R. E., Qolovchenko, X., Hamilton, N., Lawver, L., Lazarus, D. B., Lonsdale, M., Mohr, B., Nagao, T., Pereira, C. P. Q., Pudsey, C. J., Robert, C. M., Schandl, E., Spiej, J. V., Stott, L. D., Thomas, E., Thompson, K. F. M., and Wise, S. W. Jr., 113, College Station, TX (Ocean Drilling Program), 571-594, 1990.

Thomas, E.: Biogeography of the late Paleocene benthic foraminiferal extinction, in: Late Paleocene-Early Eocene Climatic and Biotic Events in the Marine and Terrestrial Records, edited by: Aubry, M. P., Lucas, S., and Berggren, W. A., Columbia University Press, New York, 214-243, 1998.

Thomas, E.: Extinction and food at the seafloor: A high-resolution benthic foraminiferal record across the Initial Eocene Thermal Maximum, Southern Ocean Site 690, in: Causes and Consequences of Globally Warm Climates in the Early Paleogene, edited by: Wing, S. L., Gingerich, P. D., Schmitz, B., and Thomas, E., Geol. S. Am. S., Boulder, Colorado, The Geological Society of America, 369, 319-332, 2003.

Thomas, E.: Cenozoic mass extinctions in the deep sea: What perturbs the largest habitat on Earth?, in: Large Ecosystem Perturbations: Causes and Consequences, edited by: Monechi, S., Coccioni, R., and Rampino, M., Geol. S. Am. S., Boulder, Colorado, The Geological Society of America, 424, 1-23, 2007.

Thomas, E. and Gooday, A. W.: Cenozoic deep-sea benthic foraminifers: Tracers for changes in oceanic productivity?, Geology, 24, 355-358, 1996.

Thomas, E. and Shackleton, N. J.: The Paleocene-Eocene benthic foraminiferal extinction and stable isotopes anomalies, Geol. Soc. Spec. Publ., 101, 401-441, 1996.

Thomas, E., Zachos, J. C., and Bralower, T. J.: Deep-Sea Environments on a Warm Earth: latest Paleocene-early Eocene, in: Warm Climates in Earth History, edited by: Huber, B., MacLeod, K., and Wing, S., Cambridge University Press, Cambridge, UK, 132-160, 2000.

Tipple, B. J., Pagani, M., Krishnan, S., Dirghangi, S. S., Galeotti, S., Agnini, C., Giusberti, L., and Rio, D.: Coupled highresolution marine and terrestrial records of carbon and hydrologic cycles variations during the Paleocene-Eocene Thermal Maximum (PETM), Earth Planet. Sc. Lett., 311, 82-92, 2011.
Tjalsma, R. C. and Lohmann, G. P.: Paleocene-Eocene bathyal and abyssal benthic foraminifera from the Atlantic Ocean, Micropaleontology Special Publication, 4, 1-90, 1983.

Torrent, J., Barro, V., and Liu, Q.: Magnetic enhancement is linked to and precedes hematite formation in aerobic soil, Geophys. Res. Lett., 33, L02401, doi:10.1029/2005GL024818, 2006.

Van Morkhoven, F. P. C. M., Berggren, W. A., and Edwards, A. S.: Cenozoic cosmopolitan deep-water benthic foraminifera, B. Cent. Rech. Expl., Mèmoire, 11, 1-421, 1986.

Van Santvoort, P. J. M., De Lange, G. J., Thomson, J., Cussen, H., and Wilson, T. R. S.: Active post-depositional oxidation of the most recent sapropel (S1) in sediments of the eastern Mediterranean Sea, Geochim. Cosmochim. Ac., 60, 4007-4024, 1996.

Von Hillebrandt, A.: Das Paläozän und seine Foraminiferenfauna im Becken von Reichenhall und Salzburg, Bayerische Akademie der Wissenschaften, Mathematisch-Naturwissenschaftliche Klasse, Abhandlungen, neue folge, München, 108, 9-180, 1962.

Waśkowska, A.: Response of Early Eocene deep-water benthic foraminifera to volcanic ash falls in the Polish Outer Carpatians: Palaeoecological implications, Palaeogeogr. Palaeocl., 305, 5064, 2011.

Wendler, I., Huber, B. T., MacLeod, K. G., and Wendler, J. E.: Stable oxygen and carbon isotope systematics of exquisitely preserved Turonian foraminifera from Tanzania - understanding isotopic signatures in fossils, Mar. Micropaleont., 102, 1-33, 2013.

Westerhold, T., Röhl, U., Laskar, J., Raffi, I., Bowles, J., Lourens, L. J., and Zachos, J. C.: On the duration of Magnetochrons C24r and $\mathrm{C} 25 \mathrm{n}$, and the timing of early Eocene global warming events: Implications from the ODP Leg 208 Walvis Ridge depth transect, Paleoceanography, 22, PA2201, doi:10.1029/2006PA001322, 2007.

Wieczorek, R., Fantle, M. S., Kump, L. R., and Ravizza, G.: Geochemical evidence for volcanic activity prior to and enhanced terrestrial weathering during the Paleocene Eocene Thermal maximum, Geochim. Cosmochim. Ac., 119, 391-410, 2013.

Wing, S. L., Harrington, G. J., Smith, F. A., Bloch, J. I., Boyer, D. M., and Freeman, K. H.: Transient floral change and rapid global warming at the Paleocene-Eocene boundary, Science, 310, 993 996, 2005.

Winguth, A. M. E., Thomas, E., and Winguth, C.: Global decline in ocean ventilation, oxygenation, and productivity during the Paleocene-Eocene Thermal Maximum: Implications for the benthic extinction, Geology, 40, 263-266, 2012.

Zachos, J. C., Pagani, M., Sloan, L. C., Thomas, E., and Billups. K.: Trends, rhythms, and aberrations in global climate $65 \mathrm{Ma}$ to present, Science, 292, 686-693, 2001.

Zachos, J. C., Röhl, U., Schellenberg, S. A., Sluijs, A., Hodell, D. A., Kelly, D. C., Thomas, E., Nicolo, M., Raffi, I., Lourens, L. J., Mccarren, H., and Kroon, D.: Rapid acidification of the ocean during the Paleocene-Eocene Thermal Maximum, Science, 308, 1611-1615, 2005.

Zachos, J. C., Schouten, S., Bohaty, S., Quattlebaum, T., Sluijs, A., Brinkhuis, H., Gibbs, S. J., and Bralower, T. J.: Extreme warming of mid latitude coastal ocean during the Paleocene-Eocene thermal maximum: inferences from TEX86 and isotope data, Geology, 34, 737-740, 2006.

Zeebe, R. E., Zachos, J. C., and Dickens, G. R.: Carbon dioxide forcing alone insufficient to explain Paleocene-Eocene Thermal Maximum warming, Nat. Geosci., 2, 576-580, 2009. 
Zeebe, R. E., Dickens, G. R., Ridgwell, A., Sluijs, A., and Thomas, E.: Onset of carbon isotope excursion at the Paleocene-Eocene Thermal Maximum took millennia, not 13 years (Comment), P. Natl. Acad. Sci. USA, 111, E1062-E1063, 2014.

Zhang, Y., Ji, J., Balsam, W. L., Liu, L., and Chen, J.: High resolution hematite and goethite records from ODP 1143, South China Sea: Co-evolution of monsoonal precipitation and El Niño over the past 600000 years, Earth Planet. Sc. Lett., 264, 136-150, 2007.
Zhou, X., Thomas, E., Rickaby, R. E. M., Winguth, A. M. E., and Lu, Z.: I/ Ca evidence for global upper ocean deoxygenation during the Paleocene-Eocene Thermal Maximum (PETM), Paleoceanography, 29, 964-975, 2014. 